Revue d'études américaines. American Studies Journal

\title{
Competing Partisan Regimes and the Transformation of the Voting Rights Act, 1965-2015
}

Jesse H. Rhodes

\section{(2) OpenEdition}

\section{Journals}

Electronic version

URL: https://journals.openedition.org/transatlantica/7437

DOI: $10.4000 /$ transatlantica. 7437

ISSN: 1765-2766

\section{Publisher}

Association française d'Etudes Américaines (AFEA)

Electronic reference

Jesse H. Rhodes, "Competing Partisan Regimes and the Transformation of the Voting Rights Act,

1965-2015", Transatlantica [Online], 1 | 2015, Online since 09 December 2015, connection on 04

February 2023. URL: http://journals.openedition.org/transatlantica/7437 ; DOl: https://doi.org/

10.4000/transatlantica.7437

This text was automatically generated on 4 February 2023.

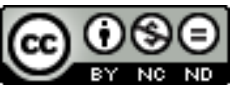

Creative Commons - Attribution-NonCommercial-NoDerivatives 4.0 International - CC BY-NC-ND 4.0 https://creativecommons.org/licenses/by-nc-nd/4.0/ 


\title{
Competing Partisan Regimes and the Transformation of the Voting Rights Act, 1965-2015
}

\author{
Jesse H. Rhodes
}

1 On June 25, 2013, in Shelby County, Alabama v. Holder, the Supreme Court struck down the coverage formula determining which states must submit proposed changes to voting rules or election systems to the Department of Justice (DOJ) or the federal courts for "preclearance" under the 1965 Voting Rights Act (VRA). In a 5-4 decision, the Court ruled that the existing coverage formula failed to take account of improvements in race relations in jurisdictions required to submit their plans for preclearance, and thus imposed an undue burden on these areas. As the majority decision announced, Congress's failure to improve the VRA "leaves us today with no choice but to declare $\$ 4(b)$ unconstitutional" (United States Supreme Court 2013:24). While the Court left open the possibility that Congress could construct a coverage formula that would pass constitutional muster, intense partisan polarization makes it extremely unlikely that Congress will devise a suitable coverage formula anytime soon. Indeed, Democrat-led efforts to resurrect the coverage formula in 2014 and 2015 were stymied by vociferous Republican opposition (Rutenberg 2015).

2 The decision was widely viewed as a major blow to enforcement of minority voting rights, because it freed previously-covered states to institute stringent voting regulations - such as "voter I.D." laws that require prospective voters to present government-issued photo identification cards in order to gain admittance to the polls that weigh heaviest on disadvantaged groups. Immediately following the decision, several southern states, including Texas and North Carolina, moved to implement restrictive voting laws that are expected to aversely affect political participation by African American, Hispanic, and young voters. The Obama administration has challenged these initiatives in federal court, but the case-by-case litigation required by Shelby County has clearly shifted the political and legal advantage to opponents of vigorous federal enforcement. 
3 Strikingly, the Shelby County decision came just a few years after Congress voted by an overwhelming margin to reauthorize the VRA with only modest changes until 2031. Indeed, during oral arguments proponents of federal preclearance pointedly noted - to no avail - that in 2006 Congress had explicitly concluded that "without the continuation of the [VRA's] protections, racial and language minority citizens will be deprived of the opportunity to exercise their right to vote, or will have their votes diluted, undermining the significant gains made by minorities in the last 40 years" (Holder et al 2013:5). In light of this recent legislative history, the Court's actions entailed a direct challenge to Congress's authority to safeguard minority voting rights under the Voting Rights Act and the Fifteenth Amendment to the United States Constitution.

4 What accounts for the peculiar pattern of legislative support and judicial indifference (or hostility) that characterize the politics surrounding the VRA today? How have patterns of stability and change in voting rights policymaking related to broader partisan and institutional struggles? This article examines the "strange career" of the Voting Rights Act (Kousser 2008) through the lens of historically-oriented political science, linking the evolution of the federal voting rights regime to broader developments in national party politics. The apparent disjuncture between the broad congressional support for the 2006 reauthorization and the Supreme Court's hostility to the Act in 2013 is just the most recent incidence of a longstanding political pattern with deep roots in partisan battles over racial equality. Indeed, the enduring tensions between the progressive tenor of the statute, on one hand, and the conservative gloss attributed by the Supreme Court (and frequently the executive branch) derive from the way partisan conflict over racial equality has been mediated by the nation's political institutions.

5 The VRA was enacted during a period of liberal Democratic dominance in American politics. Along with the Civil Rights Act of 1964, the VRA helped establish a "norm of racial equality" (Mendelberg 2001) in which African Americans and other racial minorities were to be treated as equals. Many Democratic constituencies - especially civil rights activists, liberal intellectuals, and labor groups - hoped that the VRA would pave the way to "race-conscious" policies that would enhance the power of the federal government to combat racial inequality (King and Smith 2005; King and Smith 2008). From the late 1960s onward, however, Democrats faced increasing competition from a new partisan regime organized around conservative Republican principles of free markets, limited government, and "color-blind" racial policymaking that rejected racetargeted measures.

6 While the rising Republican regime enjoyed great success in presidential politics between 1968 and 2008, it failed to secure long-term control of Congress. Consequently, it has lacked the authority to achieve a significant legislative weakening of the VRA. In truth, because they were anxious to avoid the appearance of hostility to the norm of racial equality in high-profile legislative debates over reauthorization of the VRA's provisions, Republicans repeatedly acquiesced to progressive extensions of the Act. After losing legislative battles, however, conservative Republican presidents turned to the courts and the bureaucracy, which offered opportunities for limiting the scope of the VRA without the need for legislation requiring bipartisan approval. Such "subterranean" judicial and administrative maneuvers (Hacker 2004) also allowed conservative Republican officials to circumscribe the Act while at the same time 
maintaining the public appearance of fidelity to the norm of racial equality. This political dynamic gave rise to the bifurcation of voting rights politics, in which legislative enactments often marched in the opposite direction of administrative decisions and judicial rulings.

7 The broader implications of this study are troubling. The gradual enervation of the federal voting rights regime in the face of well-documented evidence of ongoing racial discrimination in voting opportunities (McDonald and Levitas 2006; Katz et al 2006) portends the further diminution of the right to vote. The fact that unelected judges and administrators have played the central part in this drama suggests that this development is undemocratic, because those ultimately responsible cannot be held accountable for their decisions. Whether these setbacks in the "unsteady march" (Klinkner and Smith 1999) toward racial equality can be reversed remains an open question.

\section{Partisan Regimes and the Development of the VRA}

8 This article examines the development of the VRA from 1965 to the present through the lens of contending partisan regimes (Ackerman 1991; Plotke 1996; Skowronek 1997; Polsky 2001, 2012). Broadly understood, a partisan regime is "a political coalition organized under a common party label that challenges core tenets of the established political order, secures effective national governing power, broadly defines the terms of political debate, and maintains sufficient power to thwart opposition efforts to undo its principal policy, institutional, and ideological achievements" (Polsky 2012:57). A partisan regime is comprised of officeholders and the party organization, along with allied organized interests, social movements, and public intellectuals. Usually ascending to power in the wake of a major crisis, a new partisan regime attempts to address the problems facing the nation by uprooting the discredited ideology and programmatic commitments of the previous governing arrangement, paving the way for novel solutions to the challenges at hand (Plotke 1996). A successful partisan regime "reconstructs" American politics (Skowronek 1997), fundamentally altering governing commitments, transforming public policies, and reordering social relationships. Furthermore, by "stabiliz[ing] and routini[zing] governmental operations around a new set of political assumptions" (Orren and Skowronek 1999:693), a successful partisan regime insulates its achievements against the vagaries of future political struggles (Milkis 1993).

9 The concept of the "partisan regime" is a useful heuristic for thinking about partybased programmatic change (Polsky 2012). In practice, however, events rarely conspire to endow a rising partisan regime with the authority to wholly recast governing commitments (Orren and Skowronek 1999; Lieberman 2002). Indeed, "[t]he American constitutional system was designed to forestall the very accumulation of power resources that a partisan coalition finds useful in the pursuit of its agenda and the preservation of its control" (Polsky 2012:58). The Constitution created a highly fragmented political system, with political power divided both vertically between the national government and the states, and horizontally between the presidency, two separately-elected houses of Congress, and the judiciary. Thus, when a new partisan regime gains influence, political forces opposed to the ascendant order work to exploit the decentralized character of political power in American politics, attempting to 
occupy sites of authority - the bureaucracy, the federal courts, state governments, and so forth - to obstruct the ascendant regime's reconstructive efforts when and where they can (Baumgartner and Jones 1993). Furthermore, popular ideological commitments are usually difficult to dislodge entirely, meaning that opponents to a rising partisan regime can continue to make ideological appeals that will resonate with a broad audience.

10 Further complicating matters is the fact that rising partisan regimes increasingly face the problem of "institutional thickening" (Skowronek 1997) - that is, the accretion of a diverse array of professionalized interest groups, advocacy organizations, attorneys, experts, and media conglomerates with investments in the status quo. These groups possess resources they can use to obstruct thoroughgoing partisan transformations (Hacker 2004; Teles 2008). The progressive thickening of the organizational universe has added an additional layer of obstacles to the whole-scale restructuring of American politics (Laing 2013).

11 Because antagonistic forces remain in positions of political power within the system, partisan regime-builders must make concessions to their opponents in accomplishing their objectives (Orren and Skowronek 1999:696). These accommodations delimit - and may even redirect - new reform drives. The leaders of an ascendant partisan regime may find their preferred courses of action stymied by their opponents, forcing leaders to pursue alternate routes to the realization of their objectives. Equally important, the persistence of ideologies contrary to the rising regime might constrain regime leaders' capacity to institute policy changes that directly violate these durable beliefs, and thus require leaders to alter their goals and/or the means used to achieve them. At a broader level, the ongoing presence of regime opponents affects how policies and institutions change: rather than expressing the pure purposes of the ascendant partisan order, political change almost always "embodies contradictory purposes, which provide for an ongoing, churning process of development" (Schickler 2001:267).

12 In short, partisan regime development is characterized not by the straightforward conquest of the previous order by a new one, but by protracted contention between competing regimes of unequal political strength. In what follows, I trace the historical development of the VRA, linking changes in statutory text, administrative enforcement, and Supreme Court jurisprudence to shifts in the dynamics of contention between the declining liberal Democratic order and the rising conservative Republican regime.

\section{The High Tide of Liberalism and the Enactment and Early History of the VRA}

The VRA was enacted during the apex of liberal Democratic influence in American national politics (Skowronek 1997:325-60). President Lyndon Johnson had recently won a historic victory in the presidential election of 1964, trouncing conservative Republican challenger Barry Goldwater by winning 61 percent of the popular vote and more than 90 percent of the Electoral College ballots. Led by a large contingent of liberal members, the Democratic Party also held commanding majorities in the Senate and the House of Representatives (Carmines and Stimson 1989; Valelly 2004:197). 
Meanwhile, a majority of the Supreme Court subscribed to a liberal judicial philosophy highly sympathetic to the rights of racial minorities (Martin, Quinn, and Epstein 2005).

As the Johnson administration transitioned into office following the shocking murder of President John F. Kennedy, enactment of effective voting rights legislation was high on the president's agenda. Over the winter of 1964-1965, the president pressed Nicholas Katzenbach (now serving as Attorney General) to "try to figure out...what I can do to get 100 percent of people to vote," even recommending that the attorney general study whether federal postmasters might be empowered as registrars in counties where white examiners refused to enroll black voters (Johnson 1964). The president's interest was prompted by awareness that previous legislative efforts to secure African American voting rights had failed to overcome legal and extra-legal obstacles to voting (Davidson 1992:13). The push for federal legislation was further catalyzed by the brutal suppression of a carefully-staged voting rights protest in Selma, Alabama, by county and state law enforcement officers, images of which were broadcasted via the nightly news to millions of shocked viewers (Garrow 1978; Klarman 2004:440-41). "What the public felt on Monday [the day after "Bloody Sunday"]," Harry McPherson privately warned the president, "...was the deepest sense of outrage it has ever felt on the civil rights question" (McPherson 1965).

Seizing the moment, the Johnson administration developed a sweeping voting rights proposal. Not only did the administration's plan call for the statutory elimination of discriminatory literacy tests and the establishment of federal monitoring of southern elections; it also recommended that jurisdictions with low voter registration and turnout and histories of racial discrimination be subjected to federal review and "preclearance" of proposed voting changes (Landsberg 2007:148-160). Crucially, whereas previous civil rights laws had required onerous case-by-case litigation of discriminatory voting measures after they had been adopted, the preclearance proposal required covered states to demonstrate that proposed voting changes were not discriminatory before these measures could be implemented (Karlan 2008:5). To build support for his recommendations, Johnson made a dramatic speech before a joint session of Congress - viewed by more than 70 million people - in which he declared his solidarity with civil rights activists and his intention to press for strong voting rights reforms. "The Constitution says that no person shall be kept from voting because of his race or his color," Johnson (1965) asserted. "We have all sworn an oath before God to support and to defend that Constitution. We must now act in obedience to that oath." With the images of the Selma protest still vivid, Democratic congressional leaders "were confident...that President Johnson's bipartisan voting rights bill would be enacted substantially as the President outlined it" (Kenworthy 1965; Robertson 1965). The Democrats' strong majorities in both houses of Congress, coupled with support from northern liberal Republicans, permitted swift consideration of the administration's proposal. The VRA bill moved quickly through the legislative process, and was subjected to only one major legislative change: whereas the administration's bill permitted the federal courts to preclear proposed voting changes in covered jurisdictions, Congress also endowed the DOJ with preclearance authority in order to accelerate the review process (Posner 2006:90). With the civil rights movement reaching its crescendo, most representatives and senators seemed to "recogniz[e] the inevitability of the bill's triumph and the political wisdom of supporting it" (Keyssar 2000:211). In the end, the legislation was adopted by wide margins in both the House 
(328-74, with 37 southern Democrats voting in favor) and the Senate (79-18, with six southern Democrats in support) (Graham 1990:173). Congressional enthusiasm for enhanced federal enforcement of minority voting rights was sufficient to overcome a 24-day filibuster of the legislation by racial conservatives.

17 As enacted, the VRA represented a sweeping expansion of the federal government's powers to enforce minority voting rights. Section 2 of the Act imposed a nationwide prohibition on voting practices and procedures that discriminated on the basis of race or color. Sections 3 and 8 empowered the federal courts and the Attorney General, respectively, to assign federal observers to monitor the conduct of elections. Federal preclearance of proposed voting changes - the most innovative and invasive feature of the new law - was effectuated by Sections 4 and 5. Section 4 established criteria (the coverage formula) for determining which jurisdictions were subject to federal preclearance, while Section 5 determined the procedures covered jurisdictions had to follow in submitting proposed voting changes for federal approval. Other provisions of the Act outlawed literacy tests as prerequisites to voting and directed the Attorney General to challenge the constitutionality of the poll tax.

While enactment of the VRA represented a major programmatic victory for the Democratic Party, it ironically undermined the political foundations of the party's coalition. As Carmines and Huckfeldt (1992:121) note, liberal Democrats' strong stand in favor of racial equality in 1964 and 1965 "tied the future of the Democratic Party to the black electorate and racial liberalism." This stance offended many racially-conservative white southerners, who began to eschew their traditional allegiance to the Democratic Party by voting for independent - and, increasingly, Republican - candidates for political office, especially at the presidential level (Black and Black 2002; Valentino and Sears 2005). While gradual, the decline of white support for the Democratic Party after 1965 fundamentally weakened the party's electoral coalition, threatening liberal Democrats' capacity to maintain and extend federal civil rights commitments (Lublin 2004:33-65; Layman et al 2010).

Growing partisan conflict on racial issues was of considerable significance, because the VRA was vulnerable to attack by opponents of vigorous federal voting rights enforcement. Key provisions of the statute were ambiguous, and thus subject to competing interpretations. Most notably, it was unclear whether Section 5's preclearance provision applied only to laws and administrative actions directly affecting the right to register and cast a ballot, or more broadly to changes that could potentially dilute minority voting strength, such as gerrymandering or changes from single-member to at-large elections (McCrary 2006:790-1). Even if Section 5 applied to a broader range of voting changes - as the provision was interpreted after the Supreme Court's decision in Allen v. Board of Elections (1969) - the scope of this application was unclear. Consequently, implementation of the law would inevitably be influenced by the Supreme Court's interpretation of the text of the statute (as well as its Fourteenth and Fifteenth Amendment jurisprudence), which in turn was highly sensitive to changes in the composition of the Court. This meant that partisan control of the presidency - with its corresponding power to appoint justices to the Court - could play a major role in shaping future interpretation and implementation of the law.

The Act's enforcement mechanisms were also vulnerable to politicization by the executive branch. At the ground level, vigorous enforcement required a consistent willingness to enter voting rights controversies on the side of victims of discrimination. 
However, as King-Meadows (2011:9) reminds us, "while the Voting Rights Act of 1965 gives presidents a greater capacity to protect the franchise, the law cannot and does not grant presidents a greater inclination [to do so]." Presidents' discretion in implementing the Act's provisions meant that federal enforcement of minority voting rights could become a handmaiden to a president's broader political agenda, increasing or decreasing in intensity depending on the president's strategic objectives.

More subtly, given the continued importance of the norm of racial equality, politicians skeptical of vigorous federal voting rights enforcement had strong incentives to exploit administrative and judicial strategies rather than legislative proposals as their primary means for weakening the law. Unlike legislative proposals - which required congressional deliberation and thus drew extensive public and media scrutiny administrative and judicial strategies promised critics opportunities to check the scope of the Act without having to directly and publicly confront the norm of racial equality. For elected officials who sought to circumscribe federal enforcement without appearing to violate this widely-held principle, this made these "subterranean" strategies especially appealing.

The importance of presidents' discretion in administering the law was immediately made apparent. During Johnson's tenure in office, the DOJ focused, with considerable success, on registering African American voters and ensuring that they were able to cast ballots in elections. Indeed, between 1965 and 1969, "roughly a million new voters were registered...bringing African-American registration to a record 62 percent" (Keyssar 2000: 212). However, fearing backlash from southern Democratic senators against vigorous implementation of preclearance, Johnson soft-pedaled enforcement of Section 5, declining to issue regulatory guidance or exercise supervision over voting rules in covered states (Ball et al 1982). In response, many covered jurisdictions simply refused to comply with this provision: "from 1965 through 1968, neither Mississippi, Louisiana, nor any of the forty counties in North Carolina subject to Section 5 submitted a single voting change for preclearance. Alabama submitted one in 1965, but none in the next three years. Georgia made only one submission during the first three years of the Act, and Virginia made none (McDonald 1983:63)."

23 Yet, at the same time, the liberal majority on the Supreme Court pushed ahead with decisions that significantly bolstered the VRA's prospects. In South Carolina v. Katzenbach (1966), the Court sustained the central provisions of the VRA against claims that the Act violated states' rights and exceeded Congress's remedial powers under the Fifteenth Amendment. The Court's alliance with the liberal Democratic regime was evident from the text of its decision: indeed, one scholar of voting rights jurisprudence contends that "a cursory reading of the Court's opinion discloses an obvious affinity with the [Johnson administration]'s position during the congressional hearings [on the VRA], a fact that the Court did not attempt to hide" (Fuentes-Rohwer 2009:713). Then, in the landmark Allen v. Board of Elections (1969) decision, the Court went well beyond the text of the VRA to declare that Section 5 preclearance covered voting changes that potentially diluted minority voting power as well as those that simply obstructed efforts by non-whites to register and/or vote (MacCoon 1979). This meant that voting changes such as switching from district to at-large elections, moving from elective to appointive offices, changing the terms of elective offices, or increasing qualifications for office none of which actually denied African Americans the right to vote - were nonetheless subject to preclearance. In reaching its decision, the Court again indicated its sympathy 
with the objectives of the liberal Democratic regime, adopting a generous reading of the legislative history to arrive at the conclusion that Congress had always intended to make voting changes threatening the dilution of minority voting strength subject to preclearance (Kousser 2008: 685; McCrary 2003: 689-70). In truth, the Court ignored important evidence that Congress may not have intended preclearance to apply to cases of vote dilution (Eskridge 1991: 622). Allen dramatically expanded the potential impact of the VRA by subjecting a much broader range of voting policies to federal preclearance, reinforcing efforts by civil rights activists and their congressional supporters to protect minority voting rights by legislative means.

While administrative and judicial developments had cross-cutting effects during Johnson's tenure in office, they pointed to the crucial role that lower-profile political decisions could have on the scope of voting rights enforcement. These developments foreshadowed dynamics that would constitute federal voting rights policymaking in the following decades.

\section{Increasing Partisan Regime Competition and the Political Development of the VRA in the 1970s}

25 Soon after enactment of the VRA, white backlash against the civil rights movement, controversy over American involvement in the Vietnam War, divisions over the "counter-culture", and stagnating economic growth combined to weaken the liberal Democratic regime's grip on political power. In the 1966 congressional elections, Democrats lost 4 seats in the Senate and 47 seats in the House. Then, in March 1968, barely three-and-a-half years after his stunning presidential victory, Johnson announced that he would not seek reelection in 1968. The president's unexpected abandonment of reelection virtually ensured that the G.O.P. would win the White House and make further gains in Congress.

Having long dedicated himself to the quest for a Republican majority, Richard Nixon perceived that the time was ripe for a significant rightward shift in the tone of American national politics (Mason 2004: 23-30). During the 1968 campaign, he sought to exploit white middle-class resentment toward groups - including African Americans and other racial minorities - that were perceived by many whites as failing to conform to mainstream American values (O'Reilly 1995: 279-285; Mendelberg 2001:95-98). Nixon also directly challenged federal civil rights laws such as the VRA which focused enforcement in the south, "stress[ing] his belief that the South had been discriminated against too long, and that a century after the Civil War it was time to begin treating the South once again as a full-fledged part of the union (Price 1977:200)." With the Democratic Party in crisis, Nixon eked out a plurality in the popular vote (with 43.42 percent of the vote) in a three-way contest with Democratic standard-bearer Hubert Humphrey and George Wallace's American Independent candidacy.

With victory in hand, Nixon took direct aim at the Voting Rights Act. However, rather than seek outright repeal of the Act - which would have violated the norm of racial equality and exposed the administration to charges of racism - Nixon undertook a more subtle course "that would not destroy the Negro voter registration work done in the South under the act but that would assuage the continuing anger of white Southern politicians who believe they have been singled out for special, punitive attention" 
(Reed 1969). To placate southern conservatives, Nixon proposed an amendment that would have rescinded federal review of proposed voting changes under Section 5 (Kotlowski 2002:70). ${ }^{1}$ While the Nixon administration simultaneously proposed to strengthen other features of the law - in particular, by banning literacy tests nationwide, loosening state residency requirements for voting in presidential elections, and authorizing the DOJ to send voting examiners to all parts of the nation (Kotlowski 2001: 81) - these provisions were almost certainly calibrated to end the allegedly "unfair" regional focus of the law and thereby reinforce the administration's appeal with southern whites (Panetta and Gall 1971:201-02). Not incidentally, Nixon's proposal to nationalize the DOJ's examiners program would also have strained the Department's resources and thus likely made federal enforcement of minority voting rights more difficult. In testimony before Congress, Attorney General John Mitchell stated that the administration's proposal required no new resources or personnel for enforcement, apparently validating skeptics' fears that Nixon's plan was intended to undercut federal voting rights enforcement (Graham 1990:356; Bay State Banner 1969).

Indeed, the racial implications of Nixon's proposal were palpable to interested observers, who lined up in in predictable fashion in favor of or against the proposal. John Gardner, former Secretary of Health, Education, and Welfare in the Johnson administration and chairman of the National Urban Coalition, charged that Nixon's proposal would "very seriously cripple" the VRA (quoted in Finney 1970), while liberal Republican William McCulloch of Maryland questioned why the administration's plan "sweep[s] broadly into those areas where the need is least and retreat[s] from those areas where the need is greatest" (quoted in Lawson 1985:135). In contrast Strom Thurmond, the arch-conservative Republican Senator from South Carolina who had opposed the VRA in 1965, candidly declared that "If we have to have some voting rights bill, I hope it would be the [Nixon] administration's" (quoted in Weaver 1969). ${ }^{2}$

29 At the outset the prospects for Nixon's proposal seemed bright. The plan passed in the House by a 234-179 vote, with Republican and southern Democratic representatives voting overwhelmingly in favor of the legislation. However, rising awareness of the threat posed by Nixon's plan spurred civil rights activists and their liberal sympathizers in the Senate into action. With the blessing of majority leader Mike Mansfield of Montana, liberal Democrats used their control of the Senate's calendar to delay floor consideration of Nixon's controversial Supreme Court nominee, Florida jurist Harrold Carswell, until after a vote on the VRA. This forced conservative southern senators - who desperately hoped to see Carswell confirmed and thus desired a confirmation vote before liberal opposition overwhelmed his candidacy - to give up plans to filibuster the VRA extension (Lawson 1985:145-46). As J. Francis Pohlhaus of the NAACP later recalled, "[F]or once time worked in our favor, as some Senators who would normally oppose us went along with the leadership on the bill and on cloture in order to get a chance to vote for Carswell (Pohlhaus 1981)."

While racial conservatives - led by North Carolina Democrat Sam Ervin - continued efforts to stymie progress on the reauthorization, a coalition of liberal senators from both parties succeeded in moving a bill embodying their priorities to the Senate floor (Chandler 1992:29). Freed from the specter of a southern filibuster, liberal Democratic senators led by Philip Hart of Michigan, along with liberal colleagues in the GOP led by Hugh Scott of Pennsylvania, restored the preclearance clause and added a new coverage formula that extended the VRA's provisions to additional jurisdictions based 
on turnout in the 1968 presidential election. For good measure, the Senate bill added an amendment to lower the voting age to eighteen (Garrow 1978:197). The Senate legislation called for extending the law until 1975.

31 Liberal Democrats' effective use of agenda control in the Senate turned the tables on the Nixon administration and racial conservatives in the House. With the deadline for reauthorizing the temporary provisions of the VRA now rapidly approaching in August 1970, both the administration and the House needed to pass a bill quickly to avoid scuttling the landmark voting rights law and thereby creating the impression that they were overtly hostile to African Americans. Passing the Senate bill was their only realistic option: Senate liberals had warned their House colleagues that a conference committee to reconcile conflicting House and Senate bills would encourage southern senators to renew a filibuster and thereby prevent reauthorization of the law (Hunter 1970; Mansfield Sees Filibuster 1970). Moreover, while the eighteen-year-old voting provision was controversial, neither the president nor representatives in the House wanted to convey antipathy to youth political participation when thousands of young draftees were fighting and dying in Vietnam (Lawson 1985:153-55). Faced with the stark choice of the Senate legislation or no bill at all, the House reversed itself, voting 224-183 to accept the Senate's language (Graham 1990:361).

32 President Nixon thus faced two options: vetoing the bill, and sticking to principles; or accepting the legislation, and thereby avoiding the enmity of young and minority voters. As the president pondered the matter, his advisors warned that "to align ourselves with the Thurmonds and Eastlands on [this issue] would invite the label of blatant racism" and thereby have a "damaging impact on our capacity to govern" (Price 1970). ${ }^{3}$ In the end, Nixon's overweening fear of adverse public reaction led him to swallow both his opposition to "regional" legislation and his objections to enfranchisement of 18 year olds by statute and sign the Senate's version of the VRA extension into law.

Nixon's effort to dilute the VRA via statutory amendment had been turned aside by liberal Democrats with the support of liberal Republicans, who effectively exploited Senate rules and the administration's desire to avoid racial controversy to preserve Section 5's focus on the south while extending other provisions of the law nationwide. However, the legislative defeat did not bar administration officials from seeking to "accomplish by administration what [they] were unable to do through legislation," as the Leadership Conference on Civil Rights charged in April 1971 (Aronson 1971). As he wrote years later, Nixon was "determined to ensure that the young liberal lawyers in the CRD [Civil Rights Division of the DOJ] would be prevented from running wild through the South enforcing compliance with extreme or punitive requirements they had formulated in Washington, D.C." (quoted in Ball et al 1982: 67). Attorney General Mitchell, a chief architect of Nixon's anti-civil rights 1968 campaign, was assigned the task of making certain that federal "intrusion" in southern elections did not go too far. Prior to the reauthorization of the law in 1970, as McDonald (1983: 63) notes, "Attorney General Mitchell in administering Section 5 [had] excluded annexations and redistricting from coverage" in apparent contravention of the Allen decision; and had "ruled that only those changes which the federal government affirmatively proved discrimination were objectionable", thereby reversing the burden of proof established by the VRA in 1965. In 1971, under considerable pressure from liberal Democrats and civil rights activists, the DOJ finally reversed course on these crucial matters and issued 
formal guidelines to routinize the Section 5 review process (Ball 1985:441). Nonetheless, non-compliance with federal preclearance requirements remained a serious problem in southern states. Government reports documented hundreds of cases between 1972 and 1975 in which either covered jurisdictions failed to submit voting changes to the DOJ for preclearance or covered jurisdictions implemented voting changes despite objections from the DOJ (Foster 1986: 22; McDonald 1983:65-66). To a degree, Nixon was able to parlay defeat in the high-publicity realm of legislative politics into success through obscure administrative maneuvers.

Nixon also helped direct implementation of the VRA in a more conservative direction through his appointments to the Supreme Court. As, top Nixon aide John Ehrlichman explained, Nixon's ultimate objective was to "change the domestic situation through the creation of a long-lived strict-constructionist Supreme Court, composed of young Justices who would sit and rule in Nixon's own image" (Ehrlichman 1982: 115). As advisor and eventual Supreme Court appointee William H. Rehnquist candidly explained, achieving this objective would inevitably entail the erosion of federal civil rights protections, because " $\mathrm{A}$ judge who is a 'strict constructionist' in constitutional matters will generally not be favorably inclined toward claims of either criminal defendants or civil rights plaintiffs - the latter two groups having been the principal beneficiaries of the Supreme Court's 'broad constructionist' reading of the Constitution (Rehnquist 1969)."

While Nixon's first two nominees to the Supreme Court - Clement Haynsworth and Harrold Carswell - were rejected by the Senate due to financial improprieties and a history of racist statements and actions, respectively, Nixon ultimately succeeded in appointing three relatively conservative justices to the Court: Warren Burger (as chief justice, replacing the staunch liberal Earl Warren), Lewis Powell (to replace moderate liberal Hugo Black), and William Rehnquist (replacing conservative justice John Marshall Harlan II). All told, Nixon's appointees moved the Court significantly to the right, especially on racial matters (Epstein et al 2007). ${ }^{4}$

These appointees provided critical votes for decisions that narrowed the scope of minority voting rights in the 1970s. Most importantly, along with associate justice Potter Stewart, Nixon's appointees provided the crucial votes in Beer v. United States (1976), the first major reversal in minority voting rights since enactment of the VRA in 1965 (Kousser 2008: 697). In Beer, the Court held that jurisdictions covered by Section 5 were entitled to preclearance of proposed voting changes as long as there was no "retrogression" in minority voting strength - that is, as long as minority voters were not left worse off after the change. According to the Beer standard, "changes that merely perpetuate[d] a preexisting level of exclusion [were] not objectionable for having a discriminatory effect" (Karlan 2008:8, emphasis added), though changes motivated by a discriminatory purpose could still be blocked under Section 5. The Court's ruling in Beer was extremely controversial, because its narrow construction of "discriminatory effects" had virtually no basis in either the text of the statute or the relevant legislative history (Rhodes in progress, Chapter 2). Nonetheless, as a practical matter, Beer "restricted the range of voting changes that may be denied preclearance," thus limiting the ability of the DOJ and the federal courts to check discriminatory practices by covered state and local governments (Engstrom 1980).

While Nixon's administrative maneuvers and judicial appointments blunted the impact of the VRA, the fact that the president had to resort to subterranean contrivances 
testified both to the power of the norm of racial equality and to the limited progress made by conservatives in displacing liberal Democrats from their bastion of political power in Congress. The Watergate revelations - which ultimately forced Nixon's resignation from the presidency - only strengthened the political position of liberal Democrats in Congress, ensuring continuing institutional struggle between conservative Republicans and liberal Democrats for control of voting rights policy in the 1970s. In the 1974 congressional elections, held in the immediate aftermath of Nixon's resignation, liberal Democrats picked up 5 seats in the Senate (giving them a 61-39 majority) and 48 seats in the House (increasing their advantage to 291-144) (Mieczkowski 2005:61-63; Zelizer 2004).

The infusion of liberal Democrats into Congress had crucial consequences for the statutory development of the VRA, the temporary provisions of which were up for reauthorization again in 1975. Gerald Ford, who had assumed the presidency following Nixon's resignation from office, had previously exhibited little enthusiasm for vigorous federal protection of voting rights, having served as the point-man for the Nixon administration's flaccid voting rights proposal in the House of Representatives (Finney 1969; Evans and Novak 1975b). In light of the liberals' advance in Congress, however, Ford was "eager to avoid a replay of the conflicts of 1969-1970" that had marked Nixon's punishing foray into voting rights politics (Thernstrom 1987:49). Whereas Nixon had sought, without success, to dilute the VRA through legislative amendment, Ford attempted to preempt speculation about his intentions by advocating a simple five-year extension of the law without major changes (Holsendolph 1975a; Ford Still Backs 1975).

Meanwhile, many liberal Democrats had their eyes on expanding the law's reach to ensure that language minority voters were protected in their right to vote. While the VRA's prohibitions against discrimination and ban on literacy tests were intended to facilitate voting by language minority voters, they did not address other problems obstructing voting by non-English speakers, such as lack of access to languageappropriate election materials or the absence of language-specific assistance at the polls (Tucker 2009:55-56). Believing "federal statutes are inadequate to resolve problems encountered by Chicanos," language minority activists sought to amend the VRA to extend preclearance coverage to areas with concentrations of non-English speakers and require jurisdictions to provide elections materials in voters' native languages (Meyer 1974). Disturbed by contemporary reports by the United States Commission on Civil Rights which "disclosed widespread discrimination against... minorities, principally Spanish-Americans" (House Unit Moves 1975; Hunter 1976: 254-57), liberal Democrats hastened to add these proposals to the VRA. Despite some initial concerns that incorporating protections for language minorities could spark controversy and thereby jeopardize reauthorization of the law, African American civil rights groups ultimately joined with Hispanic-American, Native Alaskan, and Native American advocates in support of the expanded legislation (Holsendolph 1975b).

The House version of the legislation maintained the major provisions of the 1970 act, while requiring jurisdictions in Texas, California, Colorado, and several other states to submit proposed voting changes for preclearance. The House bill also provided for bilingual ballots and oral voting assistance for Spanish-speaking, Asian, Native American, and Inuit citizens. The legislation thus marked a major progressive expansion of the VRA, and hearkened back to the major civil rights bills of the 1960s. 
New York Democrat Herman Badillo, a major proponent of the bill, explained that "We want to show that the spirit of the 1960's still exists, and for everybody (Voting Rights Act Wins Two Rounds 1975)."

41 Due to their commanding advantage in that chamber, liberal Democrats easily turned aside hostile amendments offered by conservative Republicans (which would have eliminated provisions extending coverage to language-minority Americans and limited the proposed permanent ban on literacy tests to five years) to bring the legislation to a vote, where it was approved by an overwhelming 341-70 margin (Holsendolph 1975b; Holsendolph 1975c). However, as the Washington Post noted, the House votes on voting rights legislation in 1975 revealed that the partisan politics of voting rights had changed dramatically in the years since the original adoption of the VRA in 1965: "[Southern Democrats] had led the fierce fights against civil rights legislation in the 1960s, but this time it was Republicans...offering the softening amendments" that would have weakened the law (Efforts to Ease Voting Rights Bill Rejected 1975).

After a delay of more than a month - brought about by Senate Judiciary Committee chairman and conservative Mississippi Democrat James Eastland's ill health and absence from the Senate - the Senate took up the legislation in July 1975, less than a month before the temporary provisions of the VRA were set to expire (Eastland Agrees to Move 1975). At this point, "Democratic leaders...maintained tight parliamentary control of debate" (Rich 1975a) in an effort to limit the impact of anticipated conservative resistance to the renewal. Liberal Democratic senators' concerns were warranted: an alliance of southern Democrats and conservative Republicans again attempted to scuttle the legislation with dilatory tactics and hostile amendments (Holsendolph 1975d). However, the liberal coalition prevailed, following the House in pushing for the extension of Section 4 coverage to additional states and for additional assistance for non-English speaking voters (Senate Taking Up 1975; Senate Rejects Bid 1975).

Just as the Senate appeared to be completing work on the bill, however, President Ford made a "surprise request...to expand the coverage of [Section 5 of] the law to all states" (Madden 1975a). Ford's appeal breathed new life into a moribund amendment originally offered by conservative Democratic senator John Stennis of Mississippi (Evans and Novak 1975a). ${ }^{5}$ While facially neutral, Ford's proposal would have inevitably weakened federal protection of minority voting rights. Not only would the proposal have terminated Section 5's focus on southern states, where voting rights violations were most pronounced; it would also have strained the Department of Justice's limited resources and thereby enfeebled federal voting rights enforcement everywhere. Ford's unexpected intervention in the VRA renewal is thus best understood as contemporary observers interpreted it - that is, as an echo of Nixon's effort to appeal to aggrieved whites while maintaining the appearance of support for minority voting rights and the norm of racial equality (Evans and Novak 1975b).

The president's awkward about-face was undoubtedly the product of political calculation. Since the inauspicious beginning of his presidency, conservative activists and party notables (most prominently, arch-conservative California governor Ronald Reagan, who had opposed both the Civil Rights Act of 1964 and the Voting Rights Act of 1965) had harshly criticized Ford's perceived moderation on economic and social issues and openly discussed challenging his re-nomination as the party's presidential candidate. As Ford's 1976 campaign manager James Baker recalls, top administration 
officials "certainly were concerned about [the Reagan challenge] in May or June of ' 75 " - just as the VRA was wending its way through Congress (Baker 2010). Concerned that Reagan could win the support of the party's right wing and thereby block his renomination, Ford's request appeared calibrated to reassure restive conservatives by signaling he was "following Nixon's civil rights footsteps (Evans and Novak 1975b)."

But the president's sudden reversal also rendered him vulnerable to charges of abandonment of the principle of racial equality for crass political purposes. Massachusetts Democratic senator Edward Kennedy acidly pronounced that Ford's request "in the final hours" of Senate consideration "[did] a great deal to confuse" the administration's position on voting rights matters; while John Tunney, the liberal California Democrat managing the VRA reauthorization in the Senate, charged that Ford was "playing politics" with voting rights for the sake of his presidential prospects (Madden 1975a). In the face of this onslaught the president retreated, declaring that passage of Stennis' proposal simply "took third place [in Ford's list of priorities] behind either extension for five years or passage of the House measure" (quoted in Rich 1975b). With the president in hasty retreat, the Stennis amendment was defeated by a 38-58 vote; soon after, the Senate approved the VRA extension by a vote of 77 to 12 (Madden 1975b). The House then passed the Senate's version of the legislation 346-56. A chastened Ford signed the VRA extension into law prior to the statutory deadline (Ford Signs Bill 1975).

The struggle over voting rights legislation in 1975 represented a distant echo of the 1970 battle. Whereas Nixon made an aggressive play for southern white votes by circulating a proposal that would have substantially diluted African American voting rights, Ford only halfheartedly embraced the proposals of racial conservatives, and retreated once it became obvious that the political costs of this stance were too high. In the end, the 1975 revision of the VRA significantly strengthened the federal government's role in protecting the voting rights of racial minorities: "in addition to extending the provisions of the law for seven years [until 1982], the bill substantially broaden[ed] the law by permanently prohibiting literacy tests and by bringing Spanishspeaking Americans and other minorities under its coverage" (Ford Signs Bill 1975). Crucially, a new Section 2 established a nationwide requirement that state and local governments provide elections materials, such as "voting notices, forms, instructions, assistance, or other materials of information relating to the electoral process, including ballots", in the native languages of minority language voters (Boyd and Markman 1983:1351). Once again, the Democrats' control of Congress, coupled with the enduring strength of the norm of racial equality, blocked an attempt by a conservative Republican president to dilute minority voting rights.

Yet Ford's presidency offered other avenues for exerting conservative influence on federal voting rights enforcement. Unlike Nixon, Ford did not employ administrative stratagems in an attempt to circumscribe implementation of the VRA. ${ }^{6}$ However, like his Republican predecessor, Ford was committed to appointing conservative judges who, in his words, would support Chief Justice Warren Burger's attempts "to limit federal jurisdiction and let state courts make more judgments themselves" (quoted in Abraham 1999:276). Granted the opportunity to appoint a justice to the Supreme Court by the retirement of staunch liberal William O. Douglas, Ford selected John Paul Stevens, who was then a judge on the Seventh Circuit. While Stevens would later become a mainstay of the Court's liberal wing, in the 1970s he amassed a moderately 
conservative voting record, often voting with the bloc comprised of Nixon's conservative appointees (Epstein, Martin, Quinn and Segal 2007:18). In the important 1980 Mobile v. Bolden case, Stevens sided with the Court's conservative wing in deciding that Section 2 of the Voting Rights Act - which ordered a nationwide ban on discriminatory voting practices - only prohibited voting practices entailing purposeful discrimination on the part of elected officials. In the case at hand, this meant that the plaintiffs could not successfully challenge a Mobile, Alabama at-large voting system simply because no African American candidate had been elected under it. More broadly, the decision was widely viewed as foreclosing the possibility that minority groups could successfully challenge a policy or practice under Section 2 on the grounds that it had a racially disparate impact on the voting power of minority voters, absent additional evidence of intentional discrimination (Boyd and Markman 1983:1354). ${ }^{7}$

All in all, the Nixon-Ford era heralded an important shift in the politics of voting rights, brought about by broader developments in the structure of conflict between the nation's partisan regimes. Between 1968 and 1976, Republicans enjoyed a level of success in presidential politics that they had been denied since the election of 1960 . However, these gains were not matched in the congressional arena; in fact, liberal Democrats' influence in Congress actually increased in the latter part of the decade. Faced with staunch opposition, neither Nixon nor Ford was willing to violate the norm of racial equality through a frontal assault on the Act. Instead, both proposed amendments that - while racially neutral on their face - would have watered down enforcement of minority voting rights. When these efforts proved too politically controversial, both Nixon and Ford backed down. However, both presidents employed subterranean administrative maneuvers and judicial appointments - which were less visible to the public and thus less politically risky - to constrain implementation of the law.

This configuration of partisan and institutional conflict gave rise to a pattern of divided development in voting rights policymaking, in which the statutory text of the VRA became increasingly liberal and inclusive, even while administrative implementation and voting rights jurisprudence moved in a noticeably more conservative direction. This dynamic intensified during the 1980s and early 1990s, when two stalwart conservative Republican presidents clashed with a Congress still dominated by liberal Democrats.

\section{The Reagan "Revolution" and the Politics of Voting Rights in the Reagan, Bush I, and Clinton Eras}

50 The 1980 election campaign witnessed a major struggle over the future of American public policy. Whereas Democratic standard-bearer Jimmy Carter promised to uphold most of the commitments of the liberal Democratic regime, Republican challenger Ronald Reagan issued a fundamental challenge to the legacies of the New Deal and Great Society (Skowronek 1997:409-29). In addition to questioning core Democratic commitments in the areas of economic regulation and social welfare, Reagan cast a skeptical eye on federal civil rights laws. In the realm of voting rights, Reagan issued specific proposals that seemed calibrated to weaken the VRA without running afoul of the norm of racial equality. Echoing Ford's 1975 recommendation, Reagan proposed that Section 5's preclearance requirement be extended to all fifty states (Wolters 
1996:29-30), even though it was almost certain that this would have stretched the DOJ's modest resources and thereby eroded federal voting rights enforcement, especially in southern states.

In the election, Reagan won an impressive victory, garnering a solid 50.5 percent of the popular vote and 489 Electoral College votes. The Republican Party also won control of the Senate for the first time in three decades, and achieved significant gains in the House of Representatives. The election thus seemed to herald a major shift in federal voting rights policy. Indeed, just after the 1980 election ballots had been counted, Senator Thurmond - the incoming chairman of the Senate Judiciary Committee, with jurisdiction over the VRA - announced that he "favored repeal or revision of the Voting Rights Act to remove Federal control over local affairs" (Pear 1981a). "[T]here are people who do not support the Voting Rights Act," warned Walter E. Fountroy, DC Delegate to Congress and Chairman of the Congressional Black Caucus in a letter to the CBC's supporters. "Those who oppose the Act are organizing Now to convince Congress to weaken the Act so it will be ineffective" (Fauntroy 1981).

In the end, however, the politics of the VRA extension echoed the battles of 1970 and 1975. Liberal Democrats and their civil rights allies again turned aside a major legislative effort to weaken the VRA, and secured a 25-year extension of the law that significantly strengthened its protection of minority voting rights. Liberal Democrats' surprising victory had its roots in the impressive civil rights counter-mobilization to Mobile v. Bolden. Fearing that the decision - coupled with Reagan's election - sounded the death knell of vigorous federal enforcement of minority voting rights, major civil rights organizations engaged in an unprecedented organizational mobilization in order to maximize their influence on the reauthorization of the Act. Their primary objectives were to reauthorize the Act's preclearance provisions and establish new statutory language that clearly prohibited election rules and regulations with discriminatory effects (Pear 1981a). Just weeks after Reagan's inauguration, civil rights advocates began "devising strategy, lobbying legislators, and drafting a bill in anticipation of a long and difficult struggle" (Pear 1981b; Weinraub 1981). As Boyd and Markman (1983:1351-52) report:

The Leadership Conference on Civil Rights, to which 165 organizations belonged, hired its first full-time executive director in preparation for the legislative campaign which lay ahead. Moreover, elements of the Leadership Conference, most notably the National Urban League, began to mobilize their local affiliates for the purpose of contacting congressional offices in affected states and applying political and media pressure designed to achieve a voting majority on the House and Senate floors...The NEA [National Education Association] organized mailings to two contact members in each of the country's 435 congressional districts, and the NAACP set up telephone banks so that local members could notify their representatives of their feelings.

In Congress, Democratic Senators Edward Kennedy of Massachusetts and Daniel Patrick Moynihan of New York, along with Representatives Peter Rodino of New Jersey and Don Edwards of California, took up this agenda, "fighting hard to extend the existing law" (Ball 1981).

Meanwhile, despite Republicans' impressive gains in the elections, conservative opposition to the VRA suffered from extreme disorganization. In truth, no Republican wanted to take the lead on the matter, because (as presidential aides warned top Reagan advisor Edwin Meese) "[e]veryone agrees that there is no way the Republicans 
can win on this issue...it is more of a concern to blacks than it is to whites" (Thomas 1981). The Reagan administration adopted a official position of silence on the matter, passing the buck to the DOJ to conduct a comprehensive study of the Act. While Reagan's request was likely intended to slow progress on the reauthorization, it left conservative opponents of the VRA in Congress bereft of presidential leadership (Extending Voting Rights 1981).

In an effort to fill the void, conservative Republican congressman Henry Hyde of Illinois developed a bill in which individuals or the DOJ would have to bring suit in federal court in order to initiate preclearance against covered jurisdictions (Boyd and Markman 1983:1357). In effect, Hyde's proposal would have reversed the burden of proof under Section 5 so that "localities that wanted to change voting policies would no longer have to prove that changes were not discriminatory; instead, complaining parties would have to prove they were" (Wolters 1996:30; Pear 1981a). However, impressed (or cowed) by committee hearings "at which dozens of witnesses testified that there was a need to retain the law in basically its present form" (Pear 1981c), Hyde backed down, declaring his support for administrative preclearance, albeit with a provision to allow jurisdictions with histories of good behavior to "bail out" of coverage (Boyd and Markman 1983:1368).

The Democrats' continued control of the House, the tireless lobbying of the civil rights organizations, and the disorganization of Republican opposition led to passage of a strong VRA renewal bill in that chamber by a vote of 389-24. Not only did the House bill reauthorize all of the law's existing provisions, it also included a very strict bailout procedure and required all bailout proceedings to be heard in the Washington, DC federal circuit court, which was widely believed to be especially hospitable to voting rights claims (Roberts 1981). Additionally, as civil rights leaders had sought, the House bill restored the standard -disavowed by the Supreme Court in Mobile v. Bolden - that minority voters could challenge voting policies and practices with discriminatory effects under Section 2 of the VRA (Pear 1981d; Pear 1981e). However, the reauthorization faced stronger headwinds in the Senate, where Republicans held the majority. In that chamber, many Republicans, including Thurmond, Jesse Helms of South Carolina, and Orrin Hatch of Utah, opposed both the strong preclearance requirement under Section 5 and the "effects" standard for proving discrimination under Section 2 adopted by the House (Pear 1981f). These efforts were given a boost when the president belatedly announced his support for lenient bailout proceedings and restrictive Section 2 language (Stuart 1981; Holsendolph 1981). Led by controversial assistant attorney general for civil rights William Bradford Reynolds, Reagan administration officials mounted a vigorous campaign against any legislative changes that would have overruled Mobile v. Bolden (Days 1984: 337).

However, the success of liberal Democrats and civil rights activists in passing a strong bill in the House - coupled with heavy lobbying and public relations efforts by civil rights activists (Pear 1981g) - blunted the impact of conservative Republican resistance in the Senate. As presidential aides reiterated, fighting against the VRA in Congress had become a losing proposition:

...regardless of the intentions on how the issue should be phrased when presented to Congress in particular and the public in general, the issue will nonetheless be debated on the level of abridging and abusing someone's right to vote, rather than the administrative arguments that favor eliminating the temporary provisions... $[T]$ he issue is going to continue to be one of extreme sensitivity" (Wirthlin 1981). 

resemblance to the struggles of 1970 and 1975, respectively. As in the previous two cases, a Republican president had sought to uphold the norm of racial equality in his public rhetoric, while supporting changes that would have had the practical effect of weakening federal voting rights enforcement. Republicans in Congress had initially flocked to this banner, transforming the president's proposals into statutory language that would have circumscribed the preclearance process and weakened civil rights activists' leverage in voting litigation. Again, however, staunch Democratic opposition and Republican anxiety about violating the norm of racial equality ultimately dissuaded the G.O.P. from following through with these initiatives via the legislative process. In the end, Republicans endorsed a reauthorization that cut against virtually all of the principles they had expressed during the early months of the debate. Most significantly, under the 1982 amendments the language of Section 2 effectively overturned Mobile v. Bolden, prohibiting "state and local officials all over the country from using any voting practice or procedure that results in discrimination against blacks and other minorities" (Thornton 1982, emphasis added), regardless of whether the discrimination was intentional.

61 However - and again, like Nixon and Ford - Reagan employed his administrative and appointments powers in ways that limited the impact of these legislative changes, largely out of the view of the public and the media. There is some evidence that Section 5 enforcement slackened during Reagan's tenure. Section 5 objections declined from an average of 3.87 percent during the Nixon, Ford, and Carter presidencies to 1.02 percent under Reagan, even though Reagan's presidency coincided with a round of redistricting, which resulted in a substantial increase in the number of Section 5 submissions. The DOJ's enforcement decisions sometimes involved clashes between high-ranking political appointees at DOJ, who were more skeptical of vigorous federal enforcement, and career attorneys, who tended to favor a more rigorous application of the law. For example, as Guinier (1989:407-408) reports,

"Between 1981 and 1985, there were at least thirty instances in which [William Bradford] Reynolds [chief of the Civil Rights Division at DOJ] overruled staff attorneys who urged him to object to a voting law change which they considered discriminatory. The assistant attorney general unilaterally shifted "the advantage of time and inertia" away from racial minorities to benefit instead white elected officials." 
In a dramatic departure from previous practice, Reagan administration officials also attempted - without success - to challenge provisions of the VRA in court. Most significantly, the administration filed an amicus brief in Thornburg v. Gingles (1986) urging the Supreme Court to adopt a narrow reading of Section 2's new "discriminatory effects" language (Days 1988: 1012). However, the Court rejected the administration's position, reaffirming the language of the 1982 reauthorization and paving the way for a multitude of lawsuits alleging discriminatory effects in voting changes. ${ }^{8}$

While the administration failed to induce the federal courts to adopt its cramped view of the law in the short term, it succeeded in transforming the federal judiciary's view of voting rights matters in the long run. Like Nixon, Reagan viewed judicial appointments as a powerful tool for advancing conservative Republican objectives, especially those that could not be accomplished by legislative or administrative means (Ackerman 1988). The Reagan administration vetted potential nominees with unprecedented rigor, in order to ensure that nominees shared the administration's ambition, in the words of Attorney General Edwin Meese, to "institutionalize the Reagan revolution so it can't be set aside no matter what happens in future presidential elections" (quoted in Busch 2001:41). During his term of office, Reagan elevated William Rehnquist, a Nixon appointee, to the chief justiceship (replacing the conservative Warren Burger) and named three justices to the Supreme Court: Sandra Day O'Connor (replacing the conservative Potter Stewart), Anthony Kennedy (replacing the conservative Lewis Powell), and Antonin Scalia (filling the seat vacated by Rehnquist) (Shull 1993:165). Reagan's appointments - especially the appointment of Scalia and the elevation of Rehnquist to the chief-justiceship - had the consequence of moving the Court further to the right, especially on civil rights matters.

Joined by Clarence Thomas (an appointee of Republican George H.W. Bush), Reagan's appointees advanced the Supreme Court's voting rights jurisprudence further on the conservative course charted by the appointees of Nixon and Ford. In a series of decisions in the 1990s - Shaw v. Reno (1993), Miller v. Johnson (1995), Shaw v. Hunt (1996), and Bush v. Vera (1996) - the Court's conservative majority sharply limited states' use of race as a consideration in the creation of legislative districts (Kousser 1999:366-455). In these cases, the Court struck down state efforts to create legislative districts in which African-Americans would comprise a majority and thereby possess opportunities to elected black representatives. With these decisions, the Court's conservative members profoundly altered the politics of redistricting, recasting it in the mold envisioned by Reagan and his supporters. In particular, the elaboration of standing doctrine under the Fourteenth Amendment to incorporate novel claims of injury resulting from raceconscious redistricting provided aggrieved whites with a powerful mechanism both to challenge the gains in minority representation that had already occurred and preempt the expansion of office-holding by citizens of color (Dow 1997).

These decisions had profound consequences for voting rights enforcement. Since some states had sought to create majority-minority districts as a way of complying with Section 2's prohibition against discriminatory voting practices, the Court's decisions substantially reduced the tools available to states that sought to provide minority voters with the chance to elect candidates of their choice (Katz 2003:2374-83). Equally important, because the Department of Justice under president Bill Clinton had sought to leverage Section 5 to pressure states to adopt majority-minority districts, the Court's decisions effectively circumscribed the federal government's powers to enforce the 
rights of African American, Latino, and Asian American voters. Although the Court did allow consideration of race in redistricting decisions under limited circumstances - as in Easley v. Cromartie (2001) - as a whole the cases raised major obstacles to state efforts to create districts in which majorities or pluralities of minority citizens would have substantial opportunities to elect representatives of color (Karlan 2001:1583-84).

Then, in a series of decisions related to redistricting in Bossier Parish, Louisiana (Reno $v$. Bossier Parish I (1997) and Reno v. Bossier Parish II (2000)), the Court made it markedly more difficult for the DOJ to interpose objections to proposed voting changes under Section 5. Bossier I held that the fact that a proposed voting change would likely deny or abridge the right to vote under Section 2 of the VRA did not give the DOJ sufficient cause to deny preclearance under Section 5 (Katz 2001: 1187-88). Under Bossier II, the DOJ could no longer object to a proposed voting change simply because the proponents of the change intended to discriminate against minority voters; instead, the DOJ could only object if it found evidence that proponents of the change intended to leave minority voters even worse off than they were before (McCrary, Seaman, and Valelly 2006:303). Thus, just as the Beer decision had prohibited the DOJ from denying preclearance on the grounds that a proposed change had discriminatory effects unless the effects were also retrogressive, so did Bossier II prohibit the DOJ from denying preclearance on the grounds that a proposed change advanced discriminatory intentions unless the intentions were also retrogressive (Fuentes-Rohwer 2009:737). The National Commission on the Voting Rights Act (2006:79) has suggested that Bossier II likely contributed to a significant decline in DOJ objections to proposed voting changes in the 2000s.

68 A consideration of Reagan's record on voting rights matters suggests that the president waged a multifaceted campaign to reduce the scope of the federal role in protecting minority voting rights - and minority civil rights in general - often losing in the short term, but sowing the seeds for future victories. Crucially, Reagan's greatest achievements occurred in venues where both public attention and political accountability were lower, thus allowing the president to advance his conservative agenda without subjecting his party's reputation to excessive public censure.

Reagan's successor, George H.W. Bush, pursued a somewhat different tack. Whereas Reagan was motivated by strong conservative convictions and relished his role as an ideological crusader, Bush was a more cautious politician who sought to avoid the harsh ideological battles that he believed contributed to partisan polarization during Reagan's tenure in office (Mervin 1996). Notably, total voting rights enforcement activity increased significantly during Bush's tenure in office (compared to that of Reagan); moreover, during the final years of his presidency, the number of DOJ objections to proposed voting changes per year rose to historic highs (National Commission on the Voting Rights Act 2006: Figures 1-2). Bush also appeared uncomfortable with the scope of the Supreme Court's conservative drift on voting rights issues. In Pressley v. Etowah County (1992), in which a conservative Court ultimately ruled that changes in the budgetary authority of a county commission were not subject to preclearance, the Bush administration sided with the unsuccessful African American plaintiffs (Greenhouse 1992).

70 Perhaps unsurprisingly given his ideological ambivalence, Bush left a mixed legacy for the Court's voting rights jurisprudence. His first nominee to the Court, David Souter, was widely viewed as a moderate at the time of his appointment (Yalof 1999:192). Over 
time, however, Souter drifted significantly to the left, often voting with the Court's more liberal justices (Epstein, Martin, Quinn, and Segal 2007:18). In contrast, Bush's second nominee, Clarence Thomas, began his career on the Court as a conservative and moved further to the right over time. As noted above, during the 1990s Thomas consistently joined with the Court's other conservatives in adopting a narrow construction both of the text of the VRA and of Congress's powers to enforce the Fourteenth and Fifteenth Amendments.

71 The 1992 election returned the presidency to the Democratic Party after a long hiatus. While Democrats initially feared that Bill Clinton - an avowed "New Democrat", would soft-pedal voting rights matters, his administration adopted a surprisingly vigorous view of enforcement. ${ }^{9}$ Under Deval Patrick, Clinton's appointee to lead the Civil Rights Division, the Division strongly urged states to create majority-minority districts as a way to increase the representation of African Americans and other racial minorities. As observers later reported, "Aggressive redistricting, prompted by the aggressive actions of the President, the Justice Department, and Attorney General Janet Reno in enforcement of the Voting Rights Act, resulted in a dramatic increase in the number of Black members of Congress, especially in the south during the early 1990's" (Court Strikes Again 1997). Additionally, Clinton's DOJ sided with defenders of majorityminority districts in the major racial redistricting cases of the 1990s, leading the United States Commission on Civil Rights (2001:55) to "commend the Clinton administration for its efforts to uphold redistricting plans that ensure minority voting rights." In the end, however, the Supreme Court's wrongful districting rulings hamstrung these efforts, limiting Clinton's capacity to affect significant change via regulatory decisionmaking.

72 Considered together, the years between 1980 and 2000 - the "Age of Reagan" (Wilentz 2008) - witnessed intensifying tensions in federal voting rights policy, reinforcing a pattern that had begun in the 1970s. On one hand, the text of the VRA was liberalized, particularly through amendments that strengthened the language of Section 2. On the other hand, administration of the VRA was pushed in a much more conservative direction, primarily due to conservative Supreme Court opinions that sharply limited the use of race in redistricting and significantly narrowed the scope of the DOJ's powers to object to discriminatory voting changes. More generally, the Supreme Court's increasingly narrow view of Congress's power to remedy constitutional violations generated a string of precedents that seemed to raise questions about the continued constitutionality of the preclearance provisions of the Act. This curious pattern of development was shaped by the dynamics of partisan regime competition during the 1980s and 1990s. Conservative Republicans sought to amend the text of the VRA in ways that would likely have weakened federal enforcement of minority voting rights, but these efforts were rebuffed by liberal Democrats in Congress. Frustrated by liberal Democrats' lingering influence in Congress and wary of directly challenging the norm of racial equality, conservative Republicans worked to check federal enforcement of minority voting rights through administrative actions and judicial appointments, which were less amenable to public scrutiny and thus carried reduced political risks. Republicans' long period of control of the presidency between 1981-1992 allowed them to shift the Supreme Court's voting rights jurisprudence (and, to a lesser extent, the DOJ's administrative enforcement) further to the right, thereby narrowing the practical scope of the statute. 


\section{Bush II, Obama, and the Politics of Voting Rights from the 2006 Renewal to the Shelby County Decision}

73 In the 2000s, the conservative Republican regime reached the apogee of its influence in American politics. With the election of Republican George W. Bush in 2000 and the Republican recapture of the Senate in 2002, the party enjoyed unified control of the federal government for the first time since before the New Deal. In 2004, the G.O.P. further consolidated control of the federal government, enjoying a 55-45 advantage in the Senate and a 232-203 margin the House. The ascendance of the conservative Republican regime had important consequences for the development of the VRA. As in previous episodes of voting rights policymaking, this development took on a divided pattern, in which conservatives lost important legislative battles but won critical - and perhaps decisive - victories in the administrative and judicial arenas.

74 The story of the 2006 renewal of the Voting Rights Act resembled that of the 1982 reauthorization, and illustrated both the continuing power of liberal Democratic forces in Congress and the lingering influence of the norm of racial equality. As in 1982, civil rights activists - again fearful that Republicans' preponderant influence in national politics could spell disaster for the VRA - organized a massive multi-year lobbying and grassroots campaign in order to firm up support for the law (Lyman 2006). Civil rights activists took advantage of the opportunity presented by public attention surrounding the 40th anniversary of the law in 2005, developing a comprehensive political strategy to "ensure that the public understands the importance of this historic legislation and the continued need to ensure that the right to vote is secured for all Americans" (Leadership Conference on Civil Rights 2005). Civil rights activists' primary objective was to extend the previous version of the VRA and incorporate new legislative language overturning Bossier II and Georgia v. Ashcroft (2003), both of which narrowed the conditions under which DOJ could deny preclearance. Notably, civil rights activists did not contemplate major changes to Sections 4 and 5, even though changing geographical patterns of discrimination - and the rightward drift of the Supreme Court's voting rights jurisprudence -raised significant questions about the adequacy of these provisions. This reflected activists' pragmatic awareness that any attempt to significantly update the bill would likely have encouraged Republicans to seize control of the amendment process, to the detriment of efforts to reauthorize the VRA along progressive lines (Persily 2007:194-95).

The civil rights activists' campaign to renew the VRA had important consequences for the law's reauthorization. The early start allowed them to enlist the support of House Judiciary chairman and staunch VRA supporter James Sensenbrenner of Wisconsin before his scheduled departure from the chairmanship (Nather 2005). Hearings on the VRA organized by Sensenbrenner and voting rights point-man Mel Watt of North Carolina raised national attention to continuing racial inequities in voting rights, helped establish a documentary record of continuing discrimination against minority voters, and placed conservative Republican critics of the VRA - always wary of directly violating the norm of racial equality - on the defensive. As Roger Clegg of the conservative Center for Equal Opportunity explained, "The Republicans know that if they question the wisdom of reauthorization the Democrats will relentlessly demagogue them on the issue. They'll be called racist and accused of wanting to turn 
back the clock on civil rights. The Republicans would really like to have this off the table" (quoted in Lyman 2006). Edward Blum, the entrepreneurial conservative activist who had spearheaded numerous challenges to the VRA, agreed, arguing:

[A]part from a few courageous members of Congress, the Republican congressional leadership, cheered on by the Bush administration, is hell-bent on keeping [the preclearance] system in place. Why?...Republicans don't want to be branded as hostile to minorities, especially just months from an election. After all, every American knows how important the VRA was in securing voting rights for Southern blacks. And even though only Section 5 is up for reauthorization, Democrats will claim Republicans want to 'turn back the clock' if they voice any doubts. Who wants to rebut that charge? (Blum 2006)

Following the hearings, Sensenbrenner and Watt drew on the proposals of the civil rights community to develop a thoroughly progressive piece of legislation (Pildes 2007). The most notable features of the bill extended Sections 4 and 5 for a 25-year period; overturned Bossier II and Georgia v. Ashcroft; and extended provisions benefitting language minority voters. The duo then presented the proposal to the Senate Judiciary Committee. Testifying both to the momentum behind the bill and to Senate Republicans' desire to appear amenable (at least in public) to the reauthorization, Chairman Arlen Specter committed to an unusual "joint introduction, bicameral introduction" and to an expedited timetable for consideration of the bill (quoted in Tucker 2007:233). The apparent bipartisan concord was amplified by a joint Democratic-Republican press conference at which leaders from both parties pledged to work for swift renewal of the law (Yachnin 2006a). While Democrats had long supported renewal of the VRA as a matter of principle, Republican leaders' apparent enthusiasm for the legislation was likely shaped by more practical considerations: as the Washington Post reported, "Republican leaders...hoped that early action [on the VRA renewal] would earn goodwill from minority voters as members of Congress head into a brutally competitive fall campaign season" (quoted in Murray 2006).

Despite Republican leaders' desire to put the reauthorization behind them in the interest of partisan expediency, backbenchers in the party refused to play along. Much to the embarrassment of House Republican leaders, members of the rank-and-file forced the leadership to delay a vote on the reauthorization (Yachnin 2006b). Republican criticisms of the bill were twofold: that preclearance was unfair to southern states and violated traditional principles of federalism; and that the provisions benefiting language minorities encouraged voter fraud, discouraged immigrants from learning English, and increased the costs of elections (Persily 2007:182). Steve King, a representative of Iowa and the leader of the group, authored an angry letter to the leadership joined by dozens Republican colleagues decrying the tendency of multilingual ballots to "divide our country, increase the risk of voter error and fraud, and burden local taxpayers" (King Applauds 2006).

Conservative Republican members demanded votes on amendments that would have weakened the preclearance and language minority provisions (Yachnin 2006c). But the delay proved politically damaging to the G.O.P. Congressional Democrats "seized the chance to spotlight the rare public dissension in Republican ranks," the Baltimore Sun reported, gleefully pointing to Republican leaders' failure to win GOP backing for voting rights legislation as evidence of their hypocritical approach to civil rights matters (Neuman 2006). "You have someone [Republican Party Chairman Ken Mehlman] stand up one day and say, 'We're going to make a major outreach to African- 
American voters,' and the next day, you pull the Voting Rights Act from the floor," Mel Watt caustically remarked (quoted in Nagourney 2006).

Public shaming of the G.O.P. by civil rights activists and Democratic politicians seem to have had its intended effect on the behavior of Republican officials. Anxious to avoid further embarrassment in the run-up to the 2006 elections, House Republican leaders permitted votes on four amendments they believed would fail due to unanimous Democratic opposition and a divided Republican vote. All four amendments were defeated: however, three proposed amendments received support from a majority of the Republican caucus, pointing to enduring Republican hostility to vigorous federal voting rights enforcement (Stern 2006a; Stern 2006b). Once it was clear that conservative efforts to weaken the legislation were destined to fail, Republican lawmakers belatedly joined with their Democratic colleagues in voting in favor of the renewal.

In the Senate, consideration of the bill was long delayed by conservative Republican senators who opposed the bill on the same grounds as those articulated by their Republican counterparts in the House (Tucker 2007:246-47). However, Republican obstruction gave way when President Bush - undoubtedly seeking to avoid the appearance of GOP hostility to minority voting rights just before the 2006 elections called for immediate enactment of the House bill in a speech before the NAACP (Feldman 2006). Given that the president had previously exhibited little interest in the legislation, it is almost certain that the speech reflected a tactical, election-year "exercise in bridge-building, intended partly to strengthen ties between Republicans and black voters and partly to reassure moderate white voters with a message of reconciliation," as the New York Times perceptively reported, rather than a genuine change of faith (Stolberg 2006). Nonetheless, Bush's speech had a galvanizing effect on Senate Republicans: the legislation was brought to a floor vote later the same day, and passed the chamber 98-0. Bush signed the legislation "amid midterm election season fanfare" in an elaborate Rose Garden ceremony a week later (Loven 2006).

81 The 2006 reauthorization of the VRA renewed the provisions of the law for 25 years, until July 2031. Importantly, the 2006 renewal directly addressed the Bossier II and Georgia v. Ashcroft decisions with language that made it easier for the DOJ to interpose objections to proposed voting changes (Tucker 2007:220-22). Civil rights leaders thus won an important victory, securing a bill that was probably the best they could have attained under the political circumstances. However, the renewal failed to respond to changing political circumstances that raised questions about the efficacy of existing provisions, thus making it vulnerable to constitutional challenge by conservative groups. Since the Court was dominated by Reagan, Bush I, and Bush II nominees, such challenges - which activists such as Edward Blum promised were forthcoming - were likely to receive a favorable hearing.

While conservative Republicans did not secure major changes to the VRA through the legislative process, control of the presidency allowed them to influence the administration of the Act by other means. Bush aggressively exploited his administrative and nominations powers to circumscribe voting rights enforcement, providing further evidence that the party's legislative support for the 2006 renewal was more a matter of party reputation maintenance than of principled commitment.

83 Through his appointments policies, Bush sought to remake the Division in his conservative image. This entailed implementing an extreme version of the 
administrative politics practiced by the Reagan administration. The president granted very conservative and unrepentantly partisan figures - most notably, acting Civil Rights Division chief Bradley Schlozman and de facto Voting Section head Hans von Spakovsky - extraordinary authority over the Division's hiring and decision-making processes. These appointees exploited these powers to stack the Division with a new cadre of conservative lawyers "affiliated with conservative groups like the Federalist Society, the Heritage Foundation, or the Republican National Lawyers Association" (Morris 2009), going so far as to violate federal civil service laws prohibiting the consideration of ideology in hiring. The Division's political leadership also altered longstanding administrative procedures to increase their control over its business, giving conservative attorneys important cases, ignoring recommendations from liberal staffers, and even transferring disfavored attorneys out of the Voting Section (Yeomans 2014; Eggen 2005; Kennedy 2008; Rich 2007).

These developments had enormous consequences for the Division's operations. Especially after 2003, administration put the brakes on Section 2 enforcement: while 121 Section 2 matters were filed by the Voting Section between 2001 and 2003, only 41 additional cases were filed between 2004 and 2007 (GAO 2009: 68). But the preclearance process bore the brunt of conservative Republican hostility toward vigorous federal voting rights enforcement. Both the total number of preclearance objections (36) and the proportion of objections relative to submissions (.0008) fell precipitously during Bush's first five years in office compared to the previous decade (356 and .002, respectively) (Fuentes-Rohwer and Charles 2007: 517). The DOJ also adopted an extremely lenient preclearance policy that resulted in the approval of a number of highly dubious voting changes. For example, in 2001 the DOJ appears to have collaborated with the Mississippi state Republican Party so that a redistricting plan favoring the GOP was implemented instead of an alternative plan ordered by a Mississippi state court (Liu 2009:83). Then, in 2003, the DOJ approved the State of Texas' controversial mid-decade redistricting plan - which reduced Latino congressional representation - despite the fact that career staff unanimously recommended that an objection be interposed (Posner 2006:14). The plan was later struck down by the Supreme Court in LULAC v. Perry (2006). In 2005, the DOJ precleared stringent voter ID requirements submitted by Arizona and Georgia, even though career staff warned that the requirements would likely lead to the disenfranchisement of minority voters (Karlan 2009:22). All told, the DOJ's administration of Section 5 during Bush's tenure indicated that the president placed a relatively low priority on the protection of minority voting rights.

Bush also shaped administration of the VRA through his Supreme Court appointments. Echoing the arguments of Republican presidents Richard Nixon and Ronald Reagan, Bush claimed that he subscribed to a "strict constructionist" interpretation of the Constitution, and suggested that he sought "judges who would faithfully interpret the Constitution, and not use the courts to invent laws or dictate social policy" (Bush 2008). Like his conservative Republican predecessors, Bush aspired to use judicial appointments to institutionalize conservative activism in the judiciary for years, if not decades, to come (Goldman, Schiavoni, and Slotnik 2009). Bush's appointees to the Court - John Roberts, replacing William Rehnquist as Chief Justice; and Samuel Alito, replacing Sandra Day O'Connor - further advanced the Court's conservative drift: whereas Roberts was probably no more conservative than Rehnquist, Alito was more predictably conservative than O'Connor (Stearns 2008). Importantly, at the time of 
Roberts' confirmation hearings substantial evidence emerged from Roberts' tenure in the Reagan DOJ suggesting that the future chief justice viewed the VRA - and especially Section 2's prohibition against voting practices with "discriminatory effects" - with considerable skepticism (Smith, Goldstein, and Becker 2005; Serwer 2013). That Bush appointed Roberts with full knowledge of this history suggests he anticipated Roberts would advance this perspective on the Court, testifying to the president's ambition to use his appointments to advance his conservative voting rights agenda.

86 Bush's appointments to the Supreme Court further entrenched a conservative fivevote majority on voting rights matters. Crucially, the 2008 and 2012 elections, which witnessed the election and reelection of Democrat Barack Obama, did not disturb this majority, pointing to the critical role played by conservative appointees in hemming in the progressive thrust of the legislative language of the VRA long after their presidential patrons had departed the political scene. ${ }^{10}$ Building on the momentum of the conservative Rehnquist Court, the Roberts Court moved quickly to further limit the scope of the Act. First, in Bartlett v. Strickland (2009) the Court narrowly construed Section 2 by deciding that "a minority group must be capable of constituting a numerical majority of the voting-age population in a geographically compact area before Section 2 requires the creation of an electoral district to prevent dilution of that group's votes" (Haygood 2010). In effect, this decision further limited the circumstances under which minorities could successfully press for a minority opportunity district under Section 2.

Then, after warning in NAMUDNO $v$. Holder (2009) that the VRA's preclearance regime might be unconstitutional, the conservative Court majority dealt preclearance a potentially fatal blow in Shelby County, Alabama v. Holder (2013), striking Section 4 on the grounds that the coverage formula failed to take account of improvements in southern race relations. Criticizing Section 4's strong focus on southern states, the Court's majority flatly declared that "[d]egardless of how to look at the record [of southern discrimination against minority voters today]...no one can fairly say that it shows anything approaching the "pervasive," "flagrant," "widespread," and "rampant" discrimination that faced Congress in 1965, and that clearly distinguished the covered jurisdictions from the rest of the Nation at that time" (Supreme Court 2013:21). Congress's failure to develop a coverage formula that reflected the Court majority's view of contemporary racial realities "leaves us today with no choice but to declare $\S 4$ (b) unconstitutional" (Supreme Court 2013:24). By removing previously-covered jurisdictions from federal scrutiny, the striking of Section 4 had the effect of rendering Section 5 inoperable. More troubling, the Court's embellishment of federalism principles - especially the doctrine of "equal state sovereignty", which the Court interpreted to limit disparate treatment of states under federal law - seemed deliberately calibrated to restrain future congressional efforts to safeguard the voting rights of racial and language minorities (Hasen 2014; Blacksher and Guinier 2014).

The Obama administration decried the Court's decision, and called on Congress to work to renew the law. However, freed by Shelby County from the electoral imperative to acquiesce to the extension of a law they reviled, congressional Republicans obstructed Democrat-led efforts to reinstate preclearance in 2014 and 2015. Meanwhile, the Obama administration attempted to use other sections of the Act to block previously-covered states from adopting restrictive voting regulations, with mixed success. While the struggle over federal voting rights continues, Shelby County altered 
the balance of power in this conflict, shifting the advantage to skeptics of vigorous voting rights enforcement.

\section{Conclusion: Contending Partisan Regimes and the Development of the Voting Rights Act}

89 In finding Section 4's coverage formula unconstitutional, the Supreme Court's decision in Shelby County, Alabama v. Holder struck a serious - and quite likely decisive - blow to the VRA's preclearance regime. The decision has rightly received a great deal of attention from journalists and voting rights experts. Viewed from the longer perspective of history, however, Shelby County is merely the most recent example of a long chain of conservative voting rights decisions narrowing the scope of the VRA's progressive textual provisions and thereby circumscribing federal enforcement of minority voting rights. From this perspective, Shelby County exacerbates, in dramatic fashion, the tension between the statute's progressive text, on one hand, and conservative statutory and constitutional interpretation, on the other, that has been building since the mid-1970s.

90 As I have argued in this article, the divided development of federal voting rights policy over the past five decades reflects broader partisan struggles between a declining, but institutionally entrenched, liberal Democratic partisan regime with strong commitment to minority voting rights and a rising conservative Republican partisan regime with limited commitment to minority voting rights. As conservative Republicans have come to enjoy greater success in American electoral politics especially at the presidential level - they have repeatedly sought legislative changes that would have circumscribed federal protection of minority voting rights. However, lingering liberal Democratic influence in Congress, combined with conservatives' hesitance to directly challenge the norm of racial equality, have not only obstructed such efforts, but actually promoted the legislative expansion of minority voting rights. Conservative Republican presidents have thus sought to redirect implementation of the VRA through administrative and (especially) judicial channels, where progress on conservative goals could be made without the same risk of public disapprobation.

91 Over the course of several decades, conservative Republican presidents have succeeded in remaking the Supreme Court, ensconcing a conservative majority with a cramped view of federal voting rights enforcement. The conservative Court majority has gradually narrowed the interpretation of both Section 2 and Section 5, blunting the progressive thrust of the VRA's major textual provisions. In the end, federal preclearance of proposed voting changes succumbed not to changing racial conditions in the south, as the conservative Court majority in Shelby County maintained, but to changing partisan and ideological conditions on the Court that have given racial conservatives the majority needed to accomplish long-cherished Republican objectives via judicial means. More broadly, Republicans' delegation to a conservative-led Court of the responsibility for defanging the VRA helped protect Republican elected officials from political backlash for weakening the law themselves.

92 A major question in American politics today is whether the nation's governing institutions are up to the task of designing a federal voting rights policy that adequately protects the rights of the nation's racial and language minorities and 
accurately reflects changing patterns of voting discrimination. Without a prompt renewal of the VRA, challenges to the voting rights of minority citizens are likely to continue - if not intensify.

\section{BIBLIOGRAPHY}

Abraham, Henry, Justices, Presidents, and Senators: A History of the U.S. Supreme Court Appointments from Washington to Clinton, New York, Rowman and Littlefield, 1999.

Ackerman, Bruce, “Transformative Appointments,” Harvard Law Review 101(6), 1988, 1164-84.

Ackerman, Bruce, We The People: Foundations, Cambridge, MA, Harvard University Press, 1991.

Aronson, Arnold. Letter to Heads of National Organizations and Washington Representatives, "Help Head Off a Threat to the Voting Rights Act," April 13, 1971, Records of the Leadership Conference on Civil Rights, Part I: Subject File, Box 139, Folder 19, United States Library of Congress, Washington, DC.

Baker, James A. Interview with Richard Norton Smith, November 2, 2010, Gerald R. Ford Oral History Project, http://geraldrfordfoundation.org/centennial/oralhistory/james-a-baker/, accessed August 20, 2015.

Ball, Howard, “Voting Rights,” New York Times, July 2, 1981.

Ball, Howard et al, Compromised Compliance: Implementation of the 1965 Voting Rights Act, New York, Greenwood Press, 1982.

Ball, Howard, "The Perpetuation of Racial Vote Dilution: An Examination of Some Constraints on the Effective Administration of the 1965 Voting Rights Act, as Amended in 1982," Howard Law Journal 28(2), 1985, 433-62.

Bay State Banner. Nixon's the One!”, Bay State Banner, July 10, 1969.

Baumgartner, Frank R., and Bryan D. Jones, Agendas and Instability in American Politics, Chicago, IL, University of Chicago Press, 1993.

Black, Earl, and Merle Black, The Rise of Southern Republicans, Cambridge, MA, Harvard University Press, 2002.

Blacksher, James and Lani Guinier, "Free at Last: Rejecting Equal State Sovereignty and Restoring the Constitutional Right to Vote," Shelby County v. Holder," Harvard Law and Policy Review 8,1(2014): 39-70.

Boyd, Thomas M. and Stephen J. Markman, "The 1982 Amendments to the Voting Rights Act: A Legislative History," Washington and Lee Law Review 40(4), 1983, 1347-1428.

Busch, Andrew E., Ronald Reagan and the Politics of Freedom, Lawrence, KS, University Press of Kansas, 2001.

Bush, George W., "Remarks to the Cincinnati Chapter of the Federalist Society," Cincinnati, Ohio, October 6, 2008. 
Carmines, Edward G. and James A. Stimson, Issue Evolution: Race and the Transformation of American Politics, Princeton, NJ, Princeton University Press, 1989.

Carmines, Edward G., and Robert Huckfeldt, "Party Politics in the Wake of the Voting Rights Act," in Controversies in Minority Voting: The Voting Rights Act in Perspective, eds. Bernard Grofman and Chandler Davidson, Washington, DC, Brookings Institution, 1992, 117-34.

“Court Strikes Again,” Cleveland Call \& Post, June 26, 1997.

Davidson, Chandler, "The Voting Rights Act: A Brief History," in Controversies in Minority Voting eds. Bernard Grofman and Chandler Davidson, Washington, DC, Brookings Institution Press, 1992, 7-34.

Days, Drew S., "Turning Back the Clock: The Reagan Administration and Civil Rights," Harvard Civil Rights and Civil Liberties Law Review 19(1), 1984, 309-47.

Days, Drew S., "The Courts' Response to the Reagan Civil Rights Agenda," Vanderbilt Law Review 42(4): 1003-16.

Dow, David R. "The Equal Protection Clause and the Legislative Redistricting Cases - Some Notes Concerning the Standing of White Plaintiffs," Minnesota Law Review 81,5(1997): 1123-48.

“Eastland Agrees to Move on the Voting Rights Act," New York Times, July 17, 1975.

"Efforts to Ease Voting Rights Bill Rejected," Washington Post, June 4, 1975.

Eggen, Dan, “Staff Opinions Banned in Voting Rights Cases; Criticism of Justice Dept.'s Rights Division Grows," Washington Post, December 10, 2005.

Ehrlichman, John. Witness to Power: The Nixon Years, New York, NY: Simon and Schuster, 1982.

Engstrom, Richard, "Racial Discrimination in the Electoral Process: The Voting Rights Act and the Vote Dilution Issue," in Party Politics in the South, eds. Robert P. Steed, Lawrence W. Moreland, and Tod A. Baker, New York, Praeger Publishing, 1980, 197-213.

Epstein, Lee, Andrew D. Martin, Kevin M. Quinn, and Jeffrey A. Segal, “Ideological Drift among Supreme Court Justices: Who, When, and How Important?” Northwestern Law Review 101(4), 2007, 1483-1542.

Eskridge, William. "Reneging on History? Playing the Court/Congress/President Civil Rights Game," Californial Law Review 79,3(1991): 613-84.

Evans, Rowland, and Robert Novak, "The Incompetency Factor," Washington Post, July 31, 1975a.

Evans, Rowland, and Robert Novak, "Ford's Voting Rights Strategy," Washington Post, May 28, $1975 b$.

“Extending Voting Rights, Or Stalling?” New York Times, June 23, 1981.

Fauntroy, Walter. Letter to Supporters, April 28, 1981, Records of the Leadership Conference on Civil Rights, LCCR Issues File, Box 67, Folder 3, United States Library of Congress, Washington, DC.

Feldman, Linda, “After Long Estrangement, Bush Reaches Out to NAACP," Christian Science Monitor, July 21, 2006.

Finney, John W., “Administration Presses G.O.P. to Bar Voting Rights Extension,” New York Times, December 11, 1969.

Finney, John W., “Senate Rebuffs Southern Attack on '65 Voting Act," New York Times, March 7, 1970.

“Ford Still Backs Voting Rights Act,” New York Times, January 15, 1975. 
“Ford Signs Bill on Voting Rights," New York Times, August 7, 1975.

Foster, Lorn F., "Section 5 of the Voting Rights Act: Implementation of an Administrative Remedy," Publius 16(4), 1986, 17-28.

Fuentes-Rohwer, Luis, "Understanding the Paradoxical Case of the Voting Rights Act," Florida State Law Review 36(1), 2009, 697-763.

Fuentes-Rohwer, Luis, and Guy-Uriel E. Charles, "The Politics of Preclearance," Michigan Journal of Race and Law 12,2(2007): 513-35.

Garrow, David, Protest at Selma: Martin Luther King, Jr. and the Voting Rights Act of 1965, New Haven, CT, Yale University Press, 1978.

Gillman, Howard, "How Political Parties Can Use the Courts to Advance their Agendas: Federal Courts in the United States, 1875-1891," American Political Science Review 96(3), 2002, 511-24.

Goldman, Sheldon, Sara Schiavoni, and Elliot Slotnik," Mission Accomplished: George W. Bush's Judicial Legacy," Judicature 92(6), 2009, 258-88.

Government Accountability Office. Information on Employment Litigation, Housing and Civil Rights Enforcement, Voting, and Special Litigation Sections' Enforcement Efforts from Fiscal Years 2001 through 2007, Washington, DC: Government Accountability Office, October 2009. Graham, Hugh D., The Civil Rights Era, Oxford, UK, Oxford University Press, 1990.

Greenhouse, Linda, “In Retreat, Supreme Court Limits Scope of '65 Voting Rights Act," New York Times, January 28, 1992.

Guinier, Lani, "Keeping the Faith: Black Voters in the Post-Reagan Era," Harvard Civil Rights and Civil Liberties Law Review 24(1), 1989, 393-435.

Hacker, Jacob S., "Privatizing Risk without Privatizing the Welfare State: The Hidden Politics of Social Policy Retrenchment in the United States," American Political Science Review 98(2), 2004, $243-60$.

Hasen, Richard L,. "Shelby County and the Illusion of Minimalism," William and Mary Bill of Rights Journal 22, 3(2014): 713-46.

Haygood, Ryan P., “The Dim Side of the Bright Line: Minority Voting Opportunity After Bartlett v. Strickland," Harvard Civil Rights and Civil Liberties Law Review, 2010, http://harvardcrcl.org/ 2010/02/25/the-dim-side-of-the-bright-line-minority-voting-opportunity-after-bartlett-vstrickland-by-ryan-p-haygood/, accessed August 20, 2013.

“Helms Still Stalls Rights Bill," Washington Post, June 17, 1982.

Holder, Eric H. et al, Brief for the Respondents in Opposition, in Shelby County, Alabama v. Holder, Attorney General, Et Al, SCOTUSblog, http://sblog.s3.amazonaws.com/wp-content/ uploads/2012/09/12-96-Shelby-County-v-Holder-BIO.pdf, accessed August 19, 2013.

Holsendolph, Ernest, “Congress is Urged to Save Vote Act,” New York Times, January 11, 1975a.

Holsendolph, Ernest, “House Stands Near on Voting Rights," New York Times, May 4, 1975b.

Holsendolph, Ernest, "House Votes, 341 to 70, to Extend and Broaden Voting Rights Act," New York Times, June 5, 1975c.

Holsendolph, Ernest, "Senators Defeat Attempts to Dilute Vote Rights Bill," New York Times, July 18,1975 d. 
Holsendolph, Ernest, “Reagan Backs Modified Plan on Rights Bill,” New York Times, November 13, 1981.

“House Unit Moves to Add Areas to Voting Rights Act Coverage," New York Times, April 18, 1975.

Hunter, David H., "The 1975 Voting Rights Act and Language Minorities," Catholic University Law Review 25(1), 1976, 250-70.

Hunter, Marjorie, “Democrats Press 18-Year-Old Vote,” New York Times, April 29, 1970.

Johnson, Lyndon. Telephone conversation with Nicholas Katzenbach, December 14, 1964, Lyndon B. Johnson Presidential Recordings, as housed at the Miller Center of Public Affairs online, available at http://web2.millercenter.org/lbj/audiovisual/whrecordings/telephone/ conversations/1964/lbj_wh6412_02_6611.wav, accessed October 30, 2015.

Johnson, Lyndon, "Transcript of the Johnson Address on Voting Rights to Joint Session of Congress," New York Times, March 16, 1965.

Karlan, Pamela S., "Easing the Spring: Strict Scrutiny and Affirmative Action after the Redistricting Cases," William and Mary Law Review 43(4), 2001, 1569-1604.

Karlan, Pamela S., "Section 5 Squared: Congressional Power to Extend and Amend the Voting Rights Act," Houston Law Review 44(1), 2008, 1-31.

Karlan, Pamela S., "Lessons Learned: Voting Rights and the Bush Administration," Duke Journal of Constitutional Law and Public Policy 4(1), 2009, 17-30.

Katz, Ellen, "Federalism, Preclearance, and the Rehnquist Court," Villanova Law Review 46(5), 2001, 1179-1218.

Katz, Ellen, "Reinforcing Representation: Congressional Power to Enforce the Fourteenth and Fifteenth Amendments in the Rehnquist and Waite Courts," Michigan Law Review 101(7), 2003, 2341-2408.

Katz, Ellen et al, "Documenting Discrimination in Voting: Judicial Findings Under Section 2 of the Voting Rights Act Since 1982," University of Michigan Journal of Law Reform, 39(4), 2006, 643-772.

Kenworthy, E.W., “Congress Ready to Move Swiftly on Voting Rights,” New York Times, March 17, 1965.

Keyssar, Alexander, The Right to Vote: The Contested History of Democracy in the United States, New York, Basic Books, 2001.

Kennedy, Edward M., "Restoring the Civil Rights Division," Harvard Law and Policy Review 2,1(2008): 211-36.

King Applauds 2006. "King Applauds Decision to Give Americans Another Chance to End Bilingual Voting," Press Release, June 21, 2006, Office of Steve King, available at https:// steveking.house.gov/media-center/press-releases/king-applauds-decision-to-give-americansanother-chance-to-end-bilingual, accessed October 20, 2015.

King, Desmond S. and Rogers S. Smith, "Racial Orders in American Political Development," American Political Science Review 99(1), 2005, 75-92.

King, Desmond S. and Rogers S. Smith, "Strange Bedfellows? Polarized Politics? The Quest for Racial Equity in Contemporary America," Political Research Quarterly 61(4), 2008, 686-703. 
King-Meadows, Tyson, When the Letter Betrays the Spirit: Voting Rights Enforcement and African American Participation from Lyndon Johnson to Barack Obama, New York, Lexington Books, 2011.

Klarman, Michael J., From Jim Crow to Civil Rights: The Supreme Court and the Struggle for Racial Equality, New York, Oxford University Press, 2004.

Klinkner, Philip, and Rogers S. Smith, The Unsteady March: The Rise and Decline of Racial Equality in America, Chicago, IL, University of Chicago Press, 1999.

Kousser, J. Morgan, Colorblind Injustice: Minority Voting Rights and the Undoing of the Second Reconstruction, Chapel Hill, NC, University of North Carolina Press, 1999.

Kousser, J. Morgan, “The Strange, Ironic Career of Section 5 of the Voting Rights Act, 1965-2007," Texas Law Review 86(4), 2008, 667-775.

Kotlowski, Dean J., Nixon's Civil Rights: Politics, Principle, and Policy, Cambridge, MA, Harvard University Press, 2002.

Laing, Matthew, "Towards a Pragmatic Presidency: Exploring the Waning of Political Time," Polity 44(2), 2012, 234-59.

Landsburg, Brian, Free at Last to Vote: The Alabama Origins of the 1965 Voting Rights Act, Lawrence, KS, University Press of Kansas, 2007.

Lawson, Steven, In Pursuit of Power: Southern Blacks and Electoral Politics, 1965-1982, New York, Columbia University Press, 1985.

Lawson, Steven, Running for Freedom: Civil Rights and Black Politics in America Since 1941, Philadelphia, PA, Temple University Press, 1991.

Layman, Geoffrey C. et al, "Activists and Conflict Extension in American Party Politics," American Political Science Review 104(2), 2010, 324-46.

Leadership Conference on Civil Rights, "The Voting Rights Act at 40: The Battle is Not Yet Over," Washington, DC, Leadership Conference on Civil Rights, August 5, 2005, www.civilrights.org/ voting-rights/vra/2006/the-voting-rights-act-at-40-the-battle-is-not-yet-over.html, accessed August 21, 2013.

Lieberman, Robert C., "Ideas, Institutions, and Political Order: Explaining Political Change," American Political Science Review 96(4), 2002, 697-712.

Liu, Goodwin, "The Bush Administration and Civil Rights: Lessons Learned," Duke Journal of Law and Public Policy 4(1), 2009, 77-105.

Loven, Jennifer, "Bush Signs Voting Rights Act Extension Amid Midterm Election Season Fanfare," Eagle-Tribune, July 28, 2006.

Lublin, David, The Republican South: Democratization and Partisan Change, Princeton, NJ, Princeton University Press, 2004.

Lyman, Rick, "Extension of Voting Act is Likely Despite Criticism," New York Times, March 29, 2006.

Lyons, Richard L., "Efforts to Ease Voting Rights Bill Rejected," Washington Post, June 4, 1975.

MacCoon, John P., "The Enforcement of the Preclearance Requirement of Section 5 of the Voting Rights Act," Catholic University Law Review 29(1), 1979, 107-27.

Madden, Richard L., “Senate Modifies Voting Act Plan,” New York Times, July 24, 1975a. 
Madden, Richard L., "Senators Vote to Extend Voting Rights Act 7 Years," New York Times, July $25,1975 b$.

“Mansfield Sees Filibuster if 18-Year-Old Vote Fails,” New York Times, May 11, 1970.

Martin, Andrew D., Kevin M. Quinn, and Lee Epstein, “The Median Justice on the United States Supreme Court," North Carolina Law Review 83(1), 2005, 1275-1321.

Mason, Robert, Richard Nixon and the Quest for a New Majority, Chapel Hill, NC, University of North Carolina Press, 2004.

Mayer, Kenneth R., With the Stroke of a Pen: Executive Orders and Presidential Power, Princeton, NJ, Princeton University Press, 2001.

McCrary, Peyton, "Bringing Equality to Power: How the Federal Courts Transformed the Electoral Structure of Southern Politics 1960-1990," Journal of Constitutional Law 5(4), 2003, 665-708.

McCrary, Peyton, "How the Voting Rights Act Works: Implementation of a Civil Rights Policy, 1965-2005," South Carolina Law Review 57(1), 2006, 786-806.

McCrary, Peyton, Christopher B. Seaman, and Richard Valelly, "The End of Preclearance as We Knew It: How the Supreme Court Transformed Section 5 of the Voting Rights Act," Michigan Journal of Race and Law 11(1), 2006, 275-324.

McDonald, Laughlin, "1982 Extension of Section 5 of the Voting Rights Act of 1965: The Continued Need for Preclearance," Tennessee Law Review 51(1), 1983, 1-81.

McDonald, Laughlin, and Daniel Levitas, "The Case for Extending and Amending the Voting Rights Act: Voting Rights Litigation, 1982-2006," American Civil Liberties Union, 2007, http:// www.aclu.org/files/pdfs/votingrightsreport20060307.pdf, accessed August 19, 2013.

McGrory, Mary, “Voting Rights Make Strange Bedfellows,” Washington Post, May 9, 1982.

McMahon, Kevin, Nixon's Court: His Challenge to Judicial Liberalism and its Political Consequences, Chicago, IL, University of Chicago Press, 2011.

McPherson, Harry. Memorandum from Harry McPherson to Lyndon B. Johnson, March 12, 1965, Legislative Background Files, Voting Rights Act of 1965, Box 1, March 12, 1965 - Fauntroy et al., Lyndon B. Johnson Presidential Library, Austin, Texas.

Melber, Ari, "Republicans Hand First Hearing on Voting Rights Act to Opponent of Voting Rights Act," MSNBC.com, July 15, 2013, accessed at http://tv.msnbc.com/2013/07/15/republicans-handfirst-hearing-on-voting-rights-act-to-opponent-of-voting-rights-act/, accessed August 21, 2013.

Mendelberg, Tali, The Race Card: Campaign Strategy, Implicit Messages, and the Norm of Equality, Princeton, NJ, Princeton University Press, 2001.

Mervin, David, George Bush and the Guardianship Presidency, New York, St. Martin's Press, 1996.

Meyer, Lawrence. “Shift Debated in Voting Rights," Washington Post, December 26, 1974.

Mieczkowski, Yanek, Gerald Ford and the Challenges of the 1970s, Lexington, KY, University of Kentucky Press, 2005.

Milkis, Sidney, The President and the Parties: The Transformation of the American Party System Since the New Deal, Oxford, UK, Oxford University Press, 1993.

Morris, Rachel, “Tipping Back the Scales," Washington Monthly, September 9, 2009.

Murray, Shailagh, "Voting Rights Act Extensions Pass House Despite GOP Infighting," Washington Post, July 14, 2006. 
Nather, David, “Sensenbrenner Hailed for the Rights Stuff," CQ Weekly, October 3, 2005.

National Commission on the Voting Rights Act, Protecting Minority Voters: The Voting Rights Act at Work 1982-2005, Washington, DC, National Commission on the Voting Rights Act, 2006.

Nagourney, Adam, "Republicans Coming Up Short in Effort to Reach Out to African-American Voters," New York Times, July 18, 2006.

Neuman, Johanna, "Renewal of Voting Rights Act is Delayed," Baltimore Sun, June 22, 2006.

O’Reilly, Kenneth, Nixon's Piano: Presidents and Racial Politics from Washington to Clinton, New York, Free Press, 1995.

Orren, Karen, and Stephen Skowronek, "Regimes and Regime Building in American Government: A Review of the Literature on the 1940s," Political Science Quarterly 113(4), 1998, 689-702.

Orren, Karen, and Stephen Skowronek, The Search for American Political Development, Cambridge, UK, Cambridge University Press, 2004.

Panetta, Leon E., and Peter Gall, Bring Us Together: The Nixon Team and the Civil Rights Retreat, Philadelphia, PA, Lippincott, 1971.

Pear, Robert, "Civil Rights and Labor Leaders Urge a 10-Year Extension of Voting Act," New York Times, May 7, 1981a.

Pear, Robert, “Major Fight Expected Over Efforts to Extend Voting Rights Measure," New York Times, May 9, 1981b.

Pear, Robert, “Campaign to Extend Voting Rights Act Gains Support," New York Times, July 2, 1981c.

Pear, Robert, "As House Nears Action on Rights Bill, the Lobbyists Get Busier," New York Times, September 27, 1981d.

Pear, Robert, "Smith Backs Voting Rights Act with Changes," New York Times, November 1, 1981 e.

Pear, Robert, "Reagan Backs Voting Rights Act but Wants to Ease Requirements," New York Times, November 7, 1981f.

Pear, Robert, “61 Senators Back House-Passed Voting Rights Bill,” New York Times, December 17, $1981 \mathrm{~g}$.

Pear, Robert, “Top Justice Officials Join Battle on Voting Rights,” New York Times, Marcy 20, 1982a.

Pear, Robert, “Compromise Likely on Voting Rights,” New York Times, May 1, 1982b.

Persily, Nathaniel, “The Promise and Pitfalls of the New Voting Rights Act," Yale Law Journal 117(2), 2007, 174-254.

Pildes, Richard H., "Political Avoidance, Constitutional Theory, and the VRA," Yale Law Journal Pocket Part 117(2): 148-154.

Plotke, David, Building a Democratic Political Order: Reshaping American Liberalism in the 1930s and 1940s, Cambridge, UK, Cambridge University Press, 1996.

Pohlhaus J. Francis. Letter to the Executive Director, Director Washington Bureau, and General Counsel, NAACP, "Voting Rights Bill," February 3, 1981, Records of the NAACP, Part IX: Washington Bureau, Box 517, Folder “Voting Rights Extension, Jan.-Mar. 1981," United States Library of Congress, Washington, DC. 
Polsky, Andrew, “When Business Speaks: Political Entrepreneurship, Discourse, and Mobilization in American Partisan Regimes," Journal of Theoretical Politics 12(4), 2000, 455-76.

Polsky, Andrew, “Partisan Regimes in American Politics,” Polity 44(1), 2012, 51-80.

Posner, Mark A., “The Real Story behind the Justice Department's Implementation of Section 5 of the VRA: Vigorous Enforcement, as Intended by Congress," Duke Journal of Constitutional Law and Public Policy 1(1), 2006, 79-158.

Price, Raymond. "Voting Rights Act - to sign or veto," June 18, 1970, both in White House Central Files, Subject File: HU(Human Rights), Box 20, "Voting 6/1/70," Richard M. Nixon Presidential Library, Yorba Linda, California.

Price, Raymond. With Nixon, New York, NY: Viking Press, 1977.

Raines, Howell, “Voting Rights Act Signed by Reagan,” New York Times, June 30, 1982.

Reed, Roy, "Nixon Aides Pressing Opposing Views on Extension of the Voting Rights Act," New York Times, June 11, 1969.

Rehnquist, William H. Letter to John Ehrlichman, "RE: Judicial Selection," May 29, 1969, John D. Ehrlichman Papers, White House Special Files, Staff Member and Office Files, Alphabetical Subject File 1963(1968-1973), Box 39, Folder 510B [Supreme Court, Haynsworth Nomination] [II] [3 of 3], Richard M. Nixon Presidential Library, Yorba Linda, California.

Rich, Joseph, Testimony in "Changing Tides; Exploring the Current State of Civil Rights Enforcement within the Department of Justice," Hearing before the Subcommittee on the Constitution, Civil Rights, and Civil Liberties of the Committee on the Judiciary, House of Representatives, $110^{\text {th }}$ Congress, First Session, March 22, 2007.

Rich, Spencer, “Voting Act Debate is Restricted," Washington Post, July 20, 1975a.

Rich, Spencer. "Voting Rights Bill Modified in Senate," Washington Post, July 24, 1975b.

Roberts, Steven V., “House Vote Backs Keeping Key Parts of 1965 Voting Act," New York Times, October 6, 1981.

Roberts, Steven V., "President Backs Bipartisan Plan on Voting Law," New York Times, May 4, 1982.

Robertson, Nan, “Johnson Pressed for a Voting Rights Bill,” New York Times, March 9, 1965.

Rodriguez, Victor A., "Section 5 of the Voting Rights Act of 1965 after Boerne: The Beginning of the End of Preclearance?” California Law Review 91(3), 2003, 769-826.

Rothman, Noah, "Howard Fineman: Voting Rights 'Preclearance is Dead Unless Congress Acts Soon," Mediaite, June 25, 2013, http://www.mediaite.com/tv/howard-fineman-voting-rightspreclearance-is-dead-unless-congress-acts-soon/, accessed August 19, 2013.

Rutenberg, Jim. “Nine Years Ago, Republicans Favored Voting Rights. What Happened?” New York Times Magazine, August 12, 2015.

Schickler, Eric, Disjointed Pluralism: Institutional Innovation and the Development of the U.S. Congress, Princeton, NJ, Princeton University Press, 2001.

“Senate Taking Up Voting Rights Act,” New York Times, July 22, 1975.

“Senate Rejects Bid by South on Voting," New York Times, July 23, 1975.

Serwer, Adam, “Chief Justice Roberts' Long War Against the Voting Rights Act,” Mother Jones, February 27, 2013. 
Shull, Steven, A Kinder, Gentler, Racism? The Reagan-Bush Civil Rights Legacy, New York, M.E. Sharpe.

Skowronek, Stephen, The Politics Presidents Make: From George Washington to Bill clinton, Second Edition, Cambridge, MA, Harvard University Press, 1997.

Smith, R. Jeffrey, Amy Goldstein, and Jo Becker, "Charter Member of Reagan Vanguard," Washington Post, August 1, 2005.

Stearn, Seth, “Voting Rights Extension Passed," CQ Weekly, July 17, 2006 a.

Stearn, Seth, “Voting Rights Extension's Four Rejected Amendments,” CQ Weekly, July 17, $2006 \mathrm{~b}$. Stearns, Maxwell, "Standing at the Crossroads: The Roberts Court in Historical Perspective," Notre Dame Law Review 83(3), 2008, 875-963.

Stolberg, Sheryl Gay, "In Speech to N.A.A.C.P., Bush Offers Reconciliation," New York Times, July $21,2006$.

Stuart, Reginald, “Voting Rights Backers Assail Reagan's Stand,” New York Times, November 8, 1981.

Teles, Steven M., The Rise of the Conservative Legal Movement: The Battle for Control of the Law, Princeton, NJ, Princeton University Press, 2008.

Thernstrom, Abigail, Whose Votes Count? Affirmative Action and Minority Voting Rights, Cambridge, MA, Harvard University Press, 1987.

Thomas, Ed. Letter to Ed Meese, "Extension of Voting Rights Act," August 27, 1981, Edwin Meese III Papers, Box 20, "Voting Rights Act Materials (3)," Ronald Reagan Presidential Library, Simi Valley, California.

Thornton, Mary, “Senators Agree on Voting Act," Washington Post, May 4, 1982.

Tucker, James T., “The Politics of Persuasion: Passage of the Voting Rights Reauthorization Act of 2006," Journal of Legislation 33(1), 2007, 205-267.

Tucker, James T., "Enfranchising Language Minority Citizens: The Bilingual Election Provisions of the Voting Rights Act," Legislation and Public Policy 10(1), 2009, 195-260.

United States Commission on Civil Rights, A Bridge to One America: The Civil Rights Performance of the Clinton Administration, Washington, DC, United States Commission on Civil Rights, 2001.

United States Supreme Court, Shelby County, Alabama v. Holder, Attorney General, Et Al, Decided June 25, 2013.

Valelly, Richard M., The Two Reconstructions: The Struggle for Black Enfranchisement, Chicago, IL, University of Chicago Press, 2004.

Valentino, Nicholas A., and David O. Sears, "Old Times There are Not Forgotten: Race and Partisan Realignment in the Contemporary South," American Journal of Political Science 49(3), 2005, 672-88.

Weaver, Warren, “Vote Act Scored by Southerners," New York Times, July 10, 1969.

Wilentz, Sean, The Age of Reagan: A History 1974-2008, New York, Harper, 2008.

Wirthlin, Richard. Letter to James Baker III, Michael Deaver, and Edwin Meese III, "Voting Rights Act,” July 17, 1981, Edwin Meese III Papers, Box 20, “Voting Rights Act Materials (4)”, Ronald Reagan Presidential Library, Simi Valley, California. 
Wolters, Raymond, Right Turn: William Bradford Reynolds, the Reagan Administration, and Black Civil Rights, New Brunswick, NJ, Transaction Publishers, 1996.

Weinraub, Bernard, "Liberal Groups are Joining Forces to Defend their Goals and Gains," New York Times, March 9, 1981.

Yachnin, Jennifer, "Parties Show Unity on VRA," Roll Call, May 3, $2006 a$.

Yachnin, Jennifer, “GOP Delays Vote on VRA,” Roll Call, June 22, $2006 \mathrm{~b}$.

Yachnin, Jennifer, “VRA to Face Four Amendments," Roll Call, July 13, 2006c.

Yalof, David A., In Pursuit of Justices: Presidential Politics and the Selection of Supreme Court Nominees, Chicago, IL, University of Chicago Press, 1999.

Yeomans, William R., “The Politics of Civil Rights Enforcement,” Washburn Law Journal 53,3(2014): 509-45

Zelizer, Julian, On Capitol Hill: The Struggle to Reform Congress and its Consequences, 1948-2000, Cambridge, UK, Cambridge University Press, 2004.

\section{NOTES}

1. If adopted, this proposal would have forced civil rights leaders and the DOJ to revert to the expensive and time-consuming task of challenging each and every discriminatory voting change in court after it had been adopted, weakening federal capacity to block unconstitutional restrictions on voting rights (Kousser 2008:686).

2. Thurmond had first distinguished himself as a leading opponent of racial equality when he bolted the Democratic Party in 1948 to run an independent "States Rights Democratic Party" presidential campaign, in response to Democratic nominee Harry Truman's outreach efforts with African Americans. Since that time, Thurmond had remained an implacable opponent of federal civil rights legislation, even switching to the Republican Party in protest of the Democrats' increasing support for civil rights.

3. Price's references are to senators Strom Thurmond of South Carolina and James Eastland of Mississippi, two of the most racially conservative members of the Senate.

4. Harry Blackmun, Nixon's fourth appointee, ended up disappointing conservatives by adopting an unexpectedly liberal jurisprudence.

5. Stennis had voted against both Civil Rights Act of 1964 and the Voting Rights Act of 1965, and thus was known as an avowed opponent of civil rights legislation. Ford's apparent endorsement of Stennis' amendment thus seemed to indicate presidential approval of the Mississippi senator's transparently conservative purposes.

6. Ford's unwillingness to politicize voting rights enforcement likely stemmed from his perception that Nixon's politicization of the executive branch contributed both to the Watergate affair and to Nixon's eventual downfall.

7. However, because the Court's decision was based on its interpretation of the text of the statute - rather than on its interpretation of provisions of the United States Constitution - the Mobile decision was subject to repeal through the ordinary legislative process.

8. Notably, in the aftermath of the Court's decision, the administration instituted a more exacting reading of both Section 2 and Section 5: indeed, the DOJ began to interpose objections to proposed voting changes under Section 5 if the changes violated Section 2 (Posner 2006:96)

9. However, Clinton abandoned the nomination of Lani Guinier, a prominent voting rights attorney, to lead the Civil Rights Division in reaction to vociferous Republican criticism of her views on minority representation. 
10. While Obama has had the opportunity to appoint two justices to the Supreme Court, these appointees - Sonya Sotomayor (in 2009) and Elena Kagan (in 2010) - replaced relatively liberal justices David Souter and John Paul Stevens, respectively, and thus had little restraining influence on the Court's rightward march.

\section{ABSTRACTS}

On June 26, 2013, the Supreme Court struck down the coverage formula enabling federal preclearance of proposed voting changes in jurisdictions with documented histories of racial discrimination. This paper interprets this event as the most recent symptom of a long-term partisan and institutional struggle over the scope of federal voting rights enforcement. Lingering liberal Democratic influence in Congress, coupled with conservatives' fears of violating the norm of racial equality, obstructed Republican diminution of federal voting rights enforcement via legislation. Consequently, Republicans turned to lower-profile administrative and especially judicial venues, which offered conservative elected officials chances to circumscribe voting rights enforcement while simultaneously maintaining a public facade of support for the norm of racial equality. Over time, this dynamic has yielded a situation in which the Court has come to serve as the judicial arm of the Republican Party, at least in the realm of voting rights.

Le 26 juin 2013 la cour suprême frappa d'inconstitutionnalité la formule permettant de déterminer quelles juridictions s'étaient rendues coupables de discriminations historiques et devaient soumettre tout changement de leurs procédures électorales à la tutelle de l'Etat fédéral. Cet article présente cet événement comme la manifestation la plus récente d'une lutte institutionnelle et partisane centrée sur l'application du droit de vote. La persistance de l'influence de l'aile gauche du parti démocrate au Congrès, ainsi que la peur des républicains d'enfreindre la norme d'égalité raciale, empêchèrent les conservateurs d'affaiblir la protection du droit de vote par la voie législative. Par conséquent, les républicains se sont tournés vers les voies administratives et judiciaires, plus discrètes, qui leur permirent d'affaiblir l'application du droit de vote tout en maintenant un discours public de respect de l'égalité raciale. Au cours du temps, cette dynamique créa une situation dans laquelle la Cour Suprême est devenue le bras armé du Party républicain au moins dans le domaine du droit de vote.

\section{AUTHOR}

JESSE H. RHODES

University of Massachusetts, Amherst 